Supporting Information for

\title{
Synergistic Effects of Polymer Donor Backbone Fluorination and Nitrogenation Translate into Efficient Non-Fullerene Bulk-Heterojunction Polymer Solar Cells
}

Zhixiong Cao, ${ }^{1, \&}$ Jiale Chen, ${ }^{1, \&}$ Shengjian Liu, ${ }^{*}, 1$ Xuechen Jiao, ${ }^{, 2}$ Shanshan Ma, ${ }^{3}$ Jiaji Zhao, ${ }^{1}$ Qingduan $\mathrm{Li}^{1}{ }^{1}$ Yue-Peng Cai, ${ }^{*}, 1$ and Fei Huang $*, 3$

Dr. Z. Cao, J. Chen, Prof. S. Liu, Dr. J. Zhao, Dr. Q. Li, and Prof. Y.-P. Cai

${ }^{1}$ School of Chemistry, Guangzhou Key Laboratory of Materials for Energy Conversion and Storage, Guangdong Provincial Engineering Technology Research Center for Materials for Energy Conversion and Storage

South China Normal University (SCNU)

Guangzhou 510006, People's Republic of China

E-mail: shengjian.liu@m.scnu.edu.cn, caiyp@ scnu.edu.cn

Dr. X. Jiao

${ }^{2}$ Department of Materials Science and Engineering, Monash University, Victoria 3800, Australia

E-mail: Xuechen.Jiao@ Monash.edu

S. Ma, Prof. F. Huang

${ }^{3}$ Institute of Polymer Optoelectronic Materials and Devices, State Key Laboratory of Luminescent Materials and Devices

South China University of Technology (SCUT)

Guangzhou 510640, People's Republic of China

E-mail: msfhuang@scut.edu.cn

${ }^{\&}$ These authors contributed equally to this work. 


\section{Contents}

1. General Experimental Details ...........................................................................................................................3

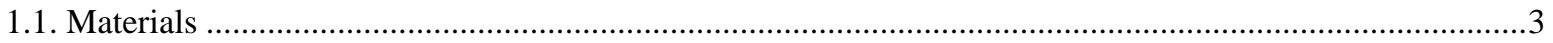

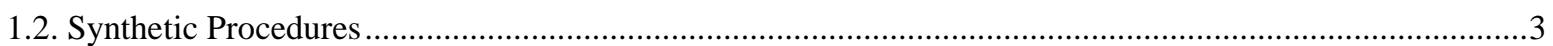

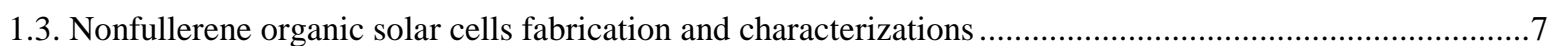

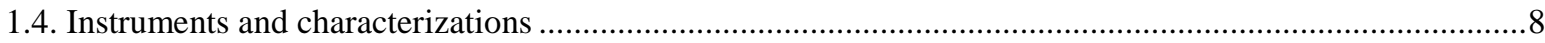

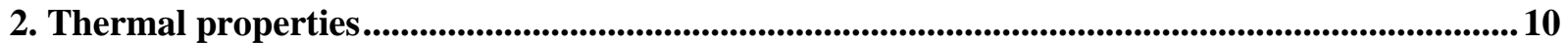

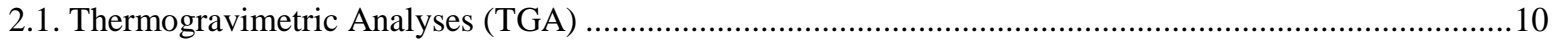

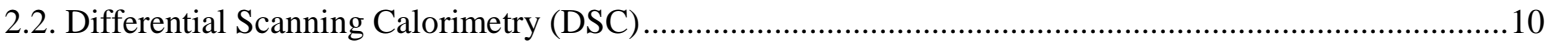

3. Additional optical and electronic parameters of the polymers and film blends ..........................11

4. Additional Data for nonfullerene PSCs and device optimization........................................14

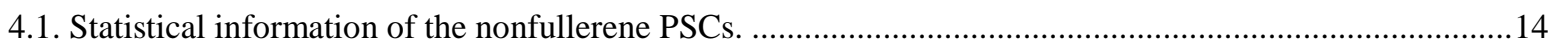

4.2. Comparison of measured $J_{\mathrm{SC}}$ and integrated $J_{\mathrm{SC}}$ from EQE measurements .....................................15

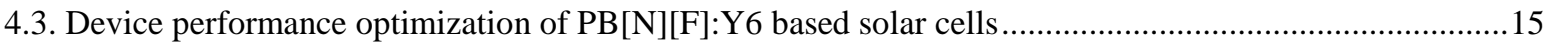

5. Photoluminecent (PL) quenching ............................................................................................................... 18

6. Space Charge Limited Current (SCLC) Measurements.....................................................................19

7. Additional morphology characterization data ..................................................................................21

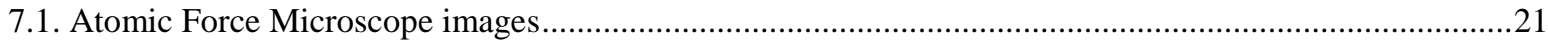

7.2. Additional GIWAXS patterns and summarized parameters...........................................................22

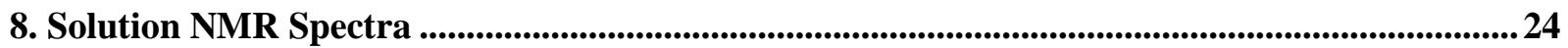

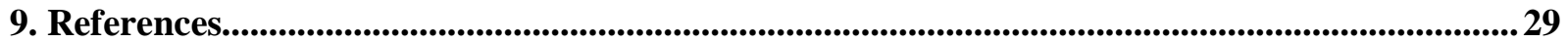




\section{General Experimental Details}

\subsection{Materials}

All reagents and solvents were purchased from commercial sources (Energy Chemical, Aldrich, Alfa Aesar, and TCI (Tokyo Chemical Industry), etc.) and used without further purification unless stated otherwise. Solvents used for syntheses were purified and dried using standard techniques. Reactions were carried out under nitrogen atmosphere. 2,2'-((2Z,2'Z)-((12,13-bis(2-ethylhexyl)-3,9-diundecyl-12,13-dihydro-[1,2,5]thiadiazolo[3,4-e]thi eno[2",3":4',5']thieno[2',3':4,5]pyrrolo[3,2-g]thieno[2',3':4,5]thieno[3,2-b]indole-2,10-diyl)bis(m ethanylylidene))bis(5,6-difluoro-3-oxo-2,3-dihydro-1H-indene-2,1-diylidene))dimalononitrile was

purchased from

eFlexPV and (3,3'-(1,3,8,10-tetraoxoanthra[2,1,9-def:6,5,10-d'e'f']diisoquinoline-2,9(1H,3H,8H,10H)-diyl)bis( N,N-dimethylpropan-1-amine oxide) (PDINO) was purchased from Derthon Co. LTD (Shenzhen, China).

\subsection{Synthetic Procedures}

2,5-bis(3-fluoro-4-octylthiophen-2-yl)thiazolo[5,4-d]thiazole (compound 3): The following reagents were added in a sequential fashion to an $25 \mathrm{~mL}$ dry microwave vial equipped with a seal septum: compound 1 (1.375 g, $2.50 \mathrm{mmol})$, compound 2 (500 mg, $1.65 \mathrm{mmol}), \mathrm{Pd}_{2}(\mathrm{dba})_{3}(45.4$ $\mathrm{mg}, 0.05 \mathrm{mmol})$ and $\mathrm{P}(\mathrm{o}-\mathrm{tol})_{3}(60.2 \mathrm{mg}, 0.20 \mathrm{mmol})$. The vial was sealed and flushed with $\mathrm{N}_{2}$, then dry chlorobenzene $(10 \mathrm{~mL})$ was added. The mixture was thoroughly degassed under $\mathrm{N}_{2}$, and then the $\mathrm{N}_{2}$ inlet was removed. After reacting at $150{ }^{\circ} \mathrm{C}$ for 18 hours, the solvent was removed under reduced pressure. The residue was purified by silica column chromatography to obtain a yellow green solid crystal (860 mg, yield $75 \%) .{ }^{1} \mathrm{H}$ NMR $\left(600 \mathrm{MHz}, \mathrm{CDCl}_{3}\right) \delta 7.03-7.02(\mathrm{~d}, J$ $=6 \mathrm{~Hz}, 2 \mathrm{H}), 2.59(\mathrm{t}, 4 \mathrm{H}), 1.69-1.64(\mathrm{~m}, 4 \mathrm{H}), 1.39-1.27(\mathrm{~m}, 20 \mathrm{H}), 0.91(\mathrm{t}, 6 \mathrm{H}) ;{ }^{13} \mathrm{C} \mathrm{NMR}\left(\mathrm{CDCl}_{3}\right.$, $100 \mathrm{MHz}), \delta$ (ppm): 158.98, 158.93, 156.16, 154.38, 150.73, 150.68, 133.37, 133.22, 122.40, $122.35,117.34,117.25,32.24,29.70,29.61,29.60,29.41,27.28,23.06,14.52 ;{ }^{19} \mathrm{~F} \mathrm{NMR}\left(\mathrm{CDCl}_{3}\right.$, $376 \mathrm{MHz}), \delta(\mathrm{ppm})=-121.33,-121.34$. 
2,5-bis(5-bromo-3-fluoro-4-octylthiophen-2-yl)thiazolo[5,4-d]thiazole (compound M1): N-bromosuccinimide (NBS, $327 \mathrm{mg}, 1.85 \mathrm{mmol}$ ) was added to a solution of compound 3 (0.5 g, $0.88 \mathrm{mmol}$ ) in $10 \mathrm{~mL}$ chloroform. The resulting mixture was stirred at room temperature for $24 \mathrm{~h}$ and then poured into $100 \mathrm{~mL}$ water. The resulting mixture was extracted with dichloromethane (DCM) three times and then concentrated in vacuum. The residue was purified by silica column chromatography to obtain a yellow green solid crystal (485 mg, yield 92\%). ${ }^{1} \mathrm{H}$ NMR (600 MHz, $\left.\mathrm{CDCl}_{3}\right) 2.60(\mathrm{t}, 4 \mathrm{H}), 1.64-1.59(\mathrm{~m}, 4 \mathrm{H}), 1.38-1.27(\mathrm{~m}, 20 \mathrm{H}), 0.90(\mathrm{t}, 6 \mathrm{H}) ;{ }^{13} \mathrm{C} \mathrm{NMR}\left(\mathrm{CDCl}_{3}\right.$, $100 \mathrm{MHz}), \delta$ (ppm): 157.93, 157.88, 154.38, 152.57, 150.85, 150.80, 133.38, 133.23, 117.48, $117.42,113.33,113.27,32.25,29.66,29.59,29.55,28.86,27.24,23.05,14.52 ;{ }^{19} \mathrm{~F} \mathrm{NMR}\left(\mathrm{CDCl}_{3}\right.$, $376 \mathrm{MHz}), \delta(\mathrm{ppm})=-116.77$.

Polymerization of PB[N][F]: The following reagents were added to a $25 \mathrm{~mL}$ dry microwave vial equipped with a seal septum in a sequential fashion: Compound M1 (88.5 mg, $0.1 \mathrm{mmol})$, compound $\mathrm{M} 2$ (124.0 mg, $0.1 \mathrm{mmol}), \mathrm{Pd}_{2}(\mathrm{dba})_{3}(2.75 \mathrm{mg}, 0.003 \mathrm{mmol})$ and $\mathrm{P}(\mathrm{o}-\mathrm{tol})_{3}(3.65 \mathrm{mg}$, $0.012 \mathrm{mmol})$. The vial was sealed and flushed with $\mathrm{N}_{2}$, then dry chlorobenzene $(5 \mathrm{~mL})$ was added. The mixture was thoroughly degassed under $\mathrm{N}_{2}$, and then the $\mathrm{N}_{2}$ inlet was removed. The mixture solution reacted at $160{ }^{\circ} \mathrm{C}$ for $24 \mathrm{~h}$. After cooling to room temperature (RT), the polymer was precipitated into methanol $(100 \mathrm{~mL})$, and filtered through a Soxhlet thimble. The polymer was extracted using Soxhlet apparatus with hexane and chloroform. The chloroform solution was concentrated and the polymer was precipitated into methanol. The precipitates were filtered and dried under vacuum to obtain dark black solid PB[N][F] (110 mg, Yield 72\%, Mn= $21.6 \mathrm{kDa}$, $\mathrm{PDI}=2.0)$. 


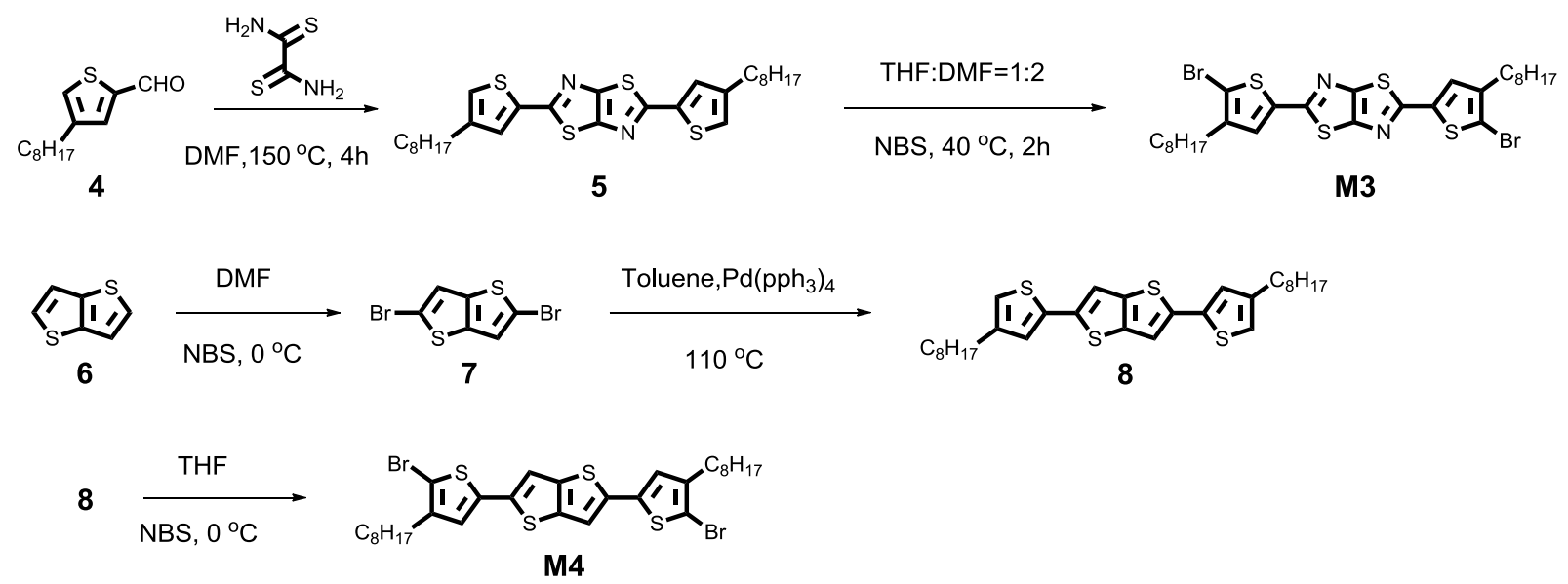

Scheme S1. Syntheses of 2,5-bis(5-bromo-4-octyl-2-thienyl)thiazolo[5,4-d]thiazole (M3) and 6,2,5-bis((5-bromo4-octyl-2-thienyl)-Thieno[3,2-b]thiophene (M4) ${ }^{1}$. Reprinted with permission from the publisher. Copyright $(\subset) 2019$, American Chemical Society

2,5-Bis(4-octyl-2-thienyl)thiazolo[5,4-d]thiazole (compound 5): Compound 4 (2.0 g, 8.9 mmol) and dithiooxamide $(0.481 \mathrm{~g}, 4.01 \mathrm{mmol})$ in $N, N$-Dimethylformamide (DMF, $48 \mathrm{ml}$ ) were heated to $150{ }^{\circ} \mathrm{C}$ for $4 \mathrm{~h}$. After cooling down to room temperature (RT), the mixture solution was poured into water and extracted with dichloromethane (DCM). The combined organic phase was dried by magnesium, filtered and concentrated in vacuum. The dark brown residue was purified by silica gel column and recrystallized from tetrahydrofuran (THF) and ethanol. The product was collected by filtration and washed several times with methanol to yield a yellow solid (1.38 g, yield $65 \%) .{ }^{1} \mathrm{H}$ NMR $\left(600 \mathrm{MHz}, \mathrm{CDCl}_{3}\right) \delta 7.40(\mathrm{~d}, \mathrm{~J}=1.3 \mathrm{~Hz}, 2 \mathrm{H}), 7.04(\mathrm{~d}, \mathrm{~J}=1.3,2 \mathrm{H}), 2.63-$

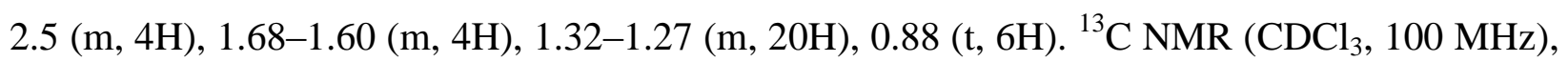
$\delta$ (ppm): 162.77, 149.63, 144.56, 137.06, 128.08, 123.56, 31.89, 30.43, 30.42, 29.42, 29.28, $29.28,22.70,14.16$.

\section{2,5-Bis(5-bromo-4-octyl-2-thienyl)thiazolo[5,4-d]thiazole}

(compound

M3):

N-bromosuccinimide (NBS, $1.08 \mathrm{~g}, 6.10 \mathrm{mmol})$ was added to a solution of compound 5 (1.5 g, $2.80 \mathrm{mmol}$ ) in $50 \mathrm{~mL}$ cosolvent of tetrahydrofuran (THF) and $N, N$-Dimethylformamide (DMF) $(1: 2 \mathrm{v} / \mathrm{v})$. The resulting mixture was stirred at $40{ }^{\circ} \mathrm{C}$ for $2 \mathrm{~h}$ and then poured into $100 \mathrm{~mL}$ water. The resulting mixture was extracted with DCM three times and then concentrated in vacuum. The residue was purified by silica gel column followed by recrystallization from THF and ethanol to 
yield a yellow solid (1.85 g, yield: $95 \%) .{ }^{1} \mathrm{H}$ NMR $\left(600 \mathrm{MHz}, \mathrm{CDCl}_{3}\right) \delta 7.28(\mathrm{~s}, 2 \mathrm{H}), 2.61-2.59(\mathrm{~m}$, $4 \mathrm{H}), 1.64-1.62(\mathrm{~m}, 4 \mathrm{H}), 1.37-1.28(\mathrm{~m}, 20 \mathrm{H}), 0.91(\mathrm{t}, 6 \mathrm{H}) .{ }^{13} \mathrm{C} \mathrm{NMR}\left(\mathrm{CDCl}_{3}, 100 \mathrm{MHz}\right): 161.86$, 149.70, 143.53, 136.72, 127.29, 113.39, 31.89, 29.63, 29.62, 29.37, 29.25, 29.23, 22.70, 14.16 .
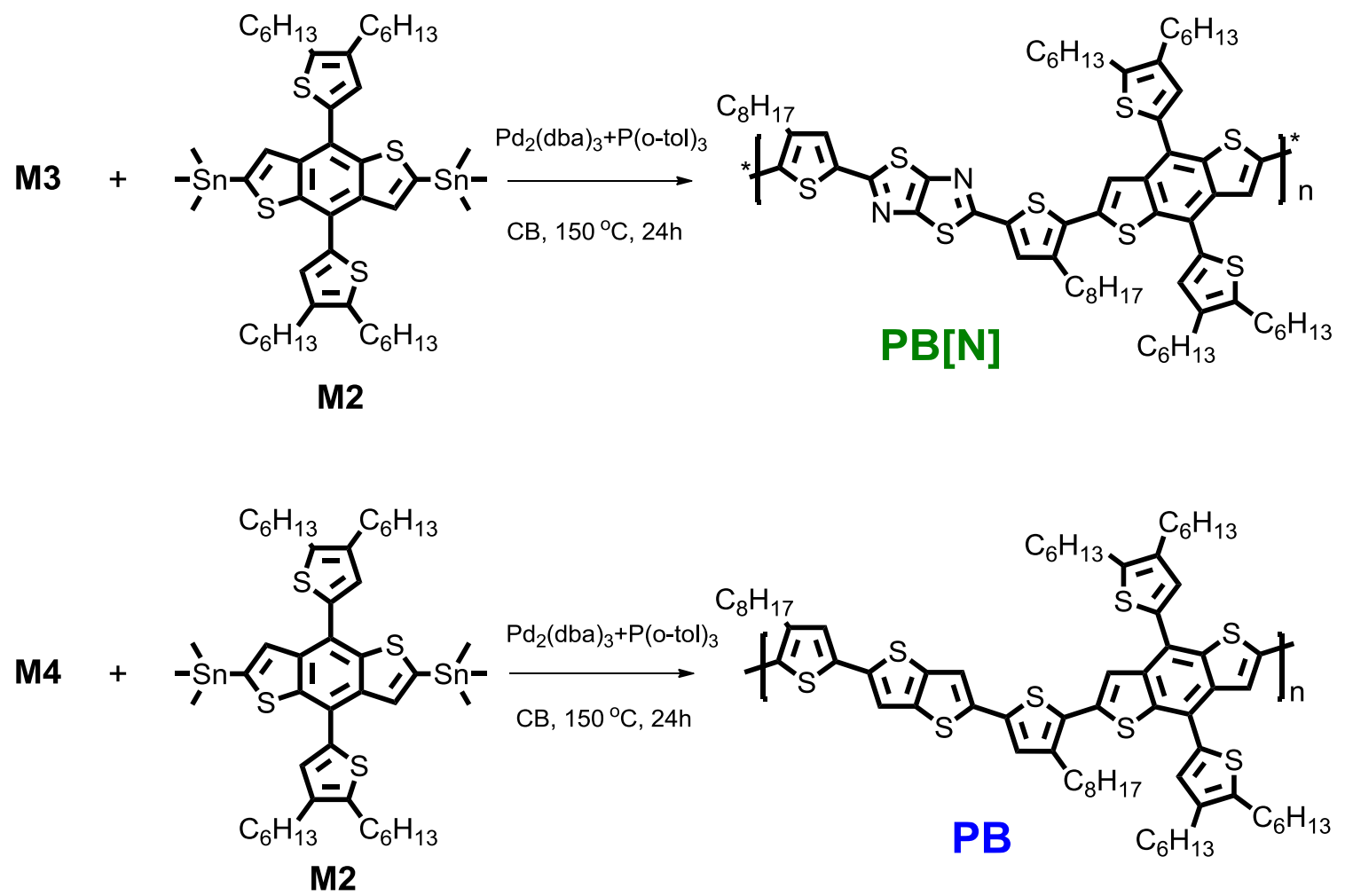

Scheme S2. The synthetic routes for the $\mathrm{PB}$ and $\mathrm{PB}[\mathrm{N}]{ }^{1}$. Reprinted with permission from the publisher. Copyright @ 2019, American Chemical Society

Polymerization of $\mathbf{P B}[\mathbf{N}]$ : The following reagents were added to a $5 \mathrm{~mL}$ dry microwave vial equipped with a seal septum in a sequential fashion: Compound M3 $(68.8 \mathrm{mg}, 0.1 \mathrm{mmol}$ ), compound M2 (101.6 mg, $0.1 \mathrm{mmol}), \mathrm{Pd}_{2}(\mathrm{dba})_{3}(2.75 \mathrm{mg}, 0.003 \mathrm{mmol})$ and $\mathrm{P}(\mathrm{o}-\mathrm{tol})_{3}(3.65 \mathrm{mg}$, $0.012 \mathrm{mmol})$. The tube was sealed and flushed with $\mathrm{N}_{2}$, and then dry chlorobenzene $(5 \mathrm{~mL})$ was added. The mixture was thoroughly degassed under $\mathrm{N}_{2}$, and then the $\mathrm{N}_{2}$ inlet was removed. The mixture solution reacted at $150{ }^{\circ} \mathrm{C}$ for $24 \mathrm{~h}$. After cooling to RT, the polymer was precipitated into methanol $(100 \mathrm{~mL})$, and filtered through a Soxhlet thimble. The polymer was extracted using Soxhlet apparatus with hexane and chloroform. The chloroform solution was concentrated and the polymer was precipitated into methanol. The precipitate was filtered and dried under vacuum to obtain dark brown solid PB[N] (116 mg, Yield 95\%, $M_{\mathrm{n}}=22.6 \mathrm{kDa}, \mathrm{PDI}=2.0$ ). 
Polymerization of PB: The following reagents were added into a $5 \mathrm{~mL}$ dry microwave vial equipped with a seal septum in a sequential fashion: compound $\mathbf{M 4}(68.6 \mathrm{mg}, 0.1 \mathrm{mmol})$, compound $\mathrm{M} 2$ (101.6 mg, $0.1 \mathrm{mmol}), \mathrm{Pd}_{2}(\mathrm{dba})_{3}(2.75 \mathrm{mg}, 0.003 \mathrm{mmol})$ and $\mathrm{P}(\mathrm{o}-\mathrm{tol})_{3}(3.65 \mathrm{mg}$, $0.012 \mathrm{mmol})$. The tube was sealed and flushed with $\mathrm{N}_{2}$, then dry chlorobenzene $(5 \mathrm{~mL})$ was added. The mixture was thoroughly degassed under $\mathrm{N}_{2}$, and then the $\mathrm{N}_{2}$ inlet was removed. The mixture solution reacted at $150{ }^{\circ} \mathrm{C}$ for $24 \mathrm{~h}$. After cooling to RT, the polymer was precipitated into methanol $(100 \mathrm{~mL})$, and filtered through a Soxhlet thimble. The polymer was extracted using Soxhlet apparatus with hexane and chloroform. The chloroform solution was concentrated and the resulting polymer was precipitated into methanol. The precipitate was filtered and dried under vacuum to obtain dark brown solid PB (54 mg, Yield 44\%, $M_{\mathrm{n}}=23.1 \mathrm{kDa}, \mathrm{PDI}=2.3$ ).

\subsection{Nonfullerene organic solar cells fabrication and characterizations}

ITO-coated glass substrates were washed using ultrasonic baths by sequentially immersing the substrates in isopropanol once, detergent once, deionized water three times, and isopropanol once, each for $15 \mathrm{~min}$, then baked at $70{ }^{\circ} \mathrm{C}$ for $3 \mathrm{~h}$ in an oven. After that, ITO substrates were treated by UV ozone for $15 \mathrm{~min}$ (NovaScan UV Ozone Cleaner), and then poly(3,4-ethylenedioxythiophene):poly(styrenesulfonate) (PEDOT:PSS, Clevios PVP Al4083 from Heraeus Precious Metals Gmbh \& Co. KG) was spin-coated onto the precleaned ITO substrates at $3500 \mathrm{rpm}$ for $30 \mathrm{~s}$ to obtain 40-nm-thick PEDOT:PSS films. ITO/PEDOT:PSS films were annealed at $150{ }^{\circ} \mathrm{C}$ for $15 \mathrm{~min}$ on a hotplate in atmosphere, and then transferred into a nitrogen-filled glovebox where the active layers were spun atop. The polymer_donor:Y6 blends $(1: 1.2, \mathrm{wt} / \mathrm{wt})$ were dissolved in chloroform (CF) with $1.0 \mathrm{vol} \%$ diphenyl ether (DPE). The total concentrations of the blend solutions were $11 \mathrm{mg} / \mathrm{mL}$. The solutions were stirred at $50^{\circ} \mathrm{C}$ for $>3 \mathrm{~h}$ in a glovebox and then spin-coated on ITO/PEDOT:PSS substrates, active layers with a thickness of $\sim 100 \mathrm{~nm}$ were obtained. The active layers were deposited under vacuum for $>30 \mathrm{~min}$ to extract the DPE residue. Then all the active layers were treated with carbon disulfide $\left(\mathrm{CS}_{2}\right)$ vapor in a petri dish for $40 \mathrm{~s}$ and then annealed at $80{ }^{\circ} \mathrm{C}$ for $2 \mathrm{~min}$. After cooling, a 5-nm-thick PDINO layer was spun atop thereafter $(1 \mathrm{mg} / \mathrm{mL}$ in methanol, spin-coated at $3000 \mathrm{rpm}$ for $10 \mathrm{~s})$. Finally, a 100-nm-thick Ag film was deposited by thermal evaporation at a pressure of $<5 \times 10^{-4} \mathrm{~Pa}$ in a glovebox to complete device fabrication. 
The characteristic current-voltage $(J-V)$ curves of the resulting nonfullerene PSCs were measured using a computer-controlled Keithley 2400 sourcemeter under $100 \mathrm{~mW} \mathrm{~cm}{ }^{-2}(1$ sun, AM 1.5G spectra, calibrated by a standard $\mathrm{Si}$ solar cell, simulator provided by SAN-EI ELECTRIC CO., LTD, Japan) and using a mask which has a square aperture with a precise area of $0.04 \mathrm{~cm}^{2}$ to define the device effective area before test. The external quantum efficiency (EQE) measurements were performed by using a QE-C system (Enlitech, Taiwan). The EQE system was calibrated with a Si photodiode before measurement.

\subsection{Instruments and characterizations}

Nuclear magnetic resonance was recorded on a Bruker AVANCE NEO - $600 \mathrm{MHz}$ spectrometer with tetramethylsilane (TMS) as the internal reference. Temperature-dependent UV-vis absorption spectra of the polymers in chlorobenzene solutions were recorded on a PerkinElmer (Lambda 365) spectrophotometer in $1 \mathrm{~cm}$ quartz cuvettes. The temperature range varied from $25^{\circ} \mathrm{C}$ to $100{ }^{\circ} \mathrm{C}$ with an interval of $10^{\circ} \mathrm{C}$ and the repeat unit concentration of polymers was ca. $1 \times 10^{-5} \mathrm{M}$. The film UV-vis absorption spectra were obtained on a SHIMADZU UV-3600 spectrophotometer. The sample films for UV-vis absorption measurements were prepared on quartz substrates. The thickness of films was determined using a KLA Tencor P6 surface profilometer. Photoelectron spectroscopy in air (PESA) measurements were recorded using a Riken Keiki PESA spectrometer (Model AC-2) with a power setting of $10 \mathrm{nW}$ and a power number of 1/3. Samples for PESA were prepared on glass substrates.

Photoluminescence (PL) measurements were carried out with a Horiba Fluoromax Plus Spectrofluorometer. The sample films for PL measurements were prepared on quartz substrates, and the active layers were prepared using exactly the same procedures as those for $J-V$ measurements. Tapping-mode atomic force microscopy (AFM) images were obtained using a NT MDT NTEGRA Microscope. The samples for AFM measurements were prepared with the structure of ITO/PEDOT:PSS $(40 \mathrm{~nm})$ /active layer. The preparation procedures were the same as those used in the device fabrication. Transmission electron microscopy (TEM) images were gained by applying a JEM-1400 PLUS Microscope operated at $120 \mathrm{keV}$. For TEM measurements, the sample films were firstly spun on PEDOT:PSS coated ITO substrates and then were immersed in deionized water. Due to the water-soluble nature of PEDOT:PSS, the active layers fell off the 
substrates and floated up to the water surface. Copper grids with no carbon film covered were used to hold-up the floating active layers, and then these grid-held film samples were put under vacuum to evaporate the water.

Synchrotron-based grazing-incidence wide-angle X-ray scattering (GIWAXS) was performed to resolve the crystallization behavior of polymer thin films. GIWAXS measurements were conducted at the small-angle X-ray scattering (SAXS)/WAXS beamline at the Australian Synchrotron ${ }^{2}$. The incident X-ray energy was chosen to be $11 \mathrm{KeV}$ and the exposure time was fixed to be $1 \mathrm{~s}$ to minimize beam damage. For each sample, diffraction patterns with a range of incidence angles from 0 to $0.2^{\circ}$ with an interval step of $0.01^{\circ}$ were collected to obtain the critical angle, where the thin-film diffraction was maximized. The two-dimensional diffraction patterns were collected using a Pilatus $1 \mathrm{M}$ detector. The sample-to-detector distance was calibrated by measuring a silver behenate reference sample. One-dimensional profiles were reduced from two-dimensional patterns by averaging the sectors of interest. The GIWAXS samples were prepared by directly spin-coating the neat or blend solutions on bare silicon wafers, and then the BHJ blend films were treated in the same manner than the optimized solar cells: the sample films on silicon wafers were firstly treated with $\mathrm{CS}_{2}$ vapor annealing for $40 \mathrm{~s}$ and then annealed at $80{ }^{\circ} \mathrm{C}$ for $2 \mathrm{~min}$, whereas the neat polymer films were as-cast for measurement. 


\section{Thermal properties}

\subsection{Thermogravimetric Analyses (TGA)}

Thermogravimetric analyses (TGA) were performed on a NETZSCH (TG 209F3) instrument at a ramp rate of $10{ }^{\circ} \mathrm{C} \cdot \mathrm{min}^{-1}$ under ultrapure $\mathrm{N}_{2}$ atmosphere, and using $\mathrm{Al}_{2} \mathrm{O}_{3}$ crucibles.

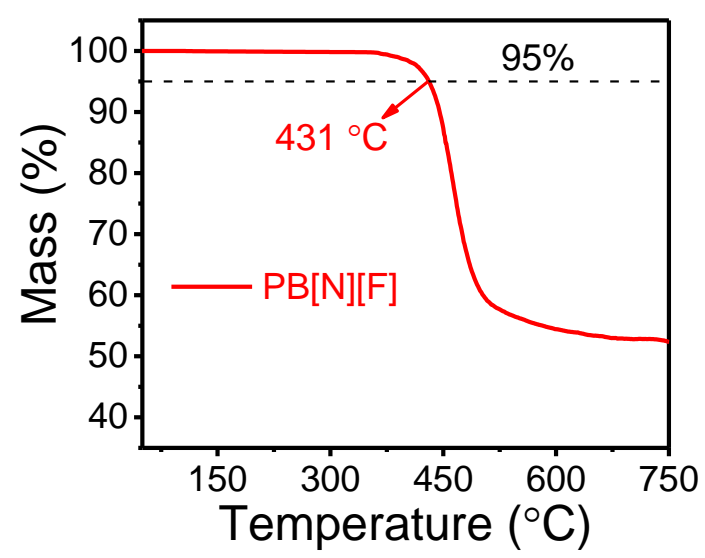

Figure S1. Thermogravimetric analyses (TGA) traces of $\mathrm{PB}[\mathrm{N}][\mathrm{F}]$.

\subsection{Differential Scanning Calorimetry (DSC)}

Differential scanning calorimetry (DSC) analyses were conducted on a NETZSCH (DSC 200F3) apparatus using Al crucibles. The heating and cooling rates were $20 / 40{ }^{\circ} \mathrm{C} \cdot \mathrm{min}^{-1}$ for the first circle and $10 / 10^{\circ} \mathrm{C} \cdot \mathrm{min}^{-1}$ for the second, respectively.

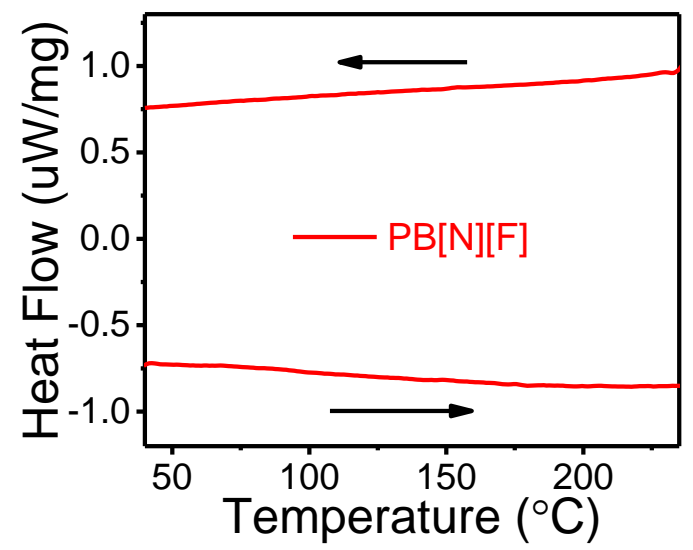

Figure S2. Differential scanning calorimetry (DSC) traces of the $2^{\text {nd }}$ cycle of polymer PB[N][F]. Traces collected at a scan rate of $10{ }^{\circ} \mathrm{C} \mathrm{min}-1$ between $40{ }^{\circ} \mathrm{C}$ and $235{ }^{\circ} \mathrm{C}$ (temperatures converted and reported in ${ }^{\circ} \mathrm{C}$ on each plot); heating: bottom traces, cooling: upper traces. 


\section{Additional optical and electronic parameters of the polymers and film}

\section{blends}

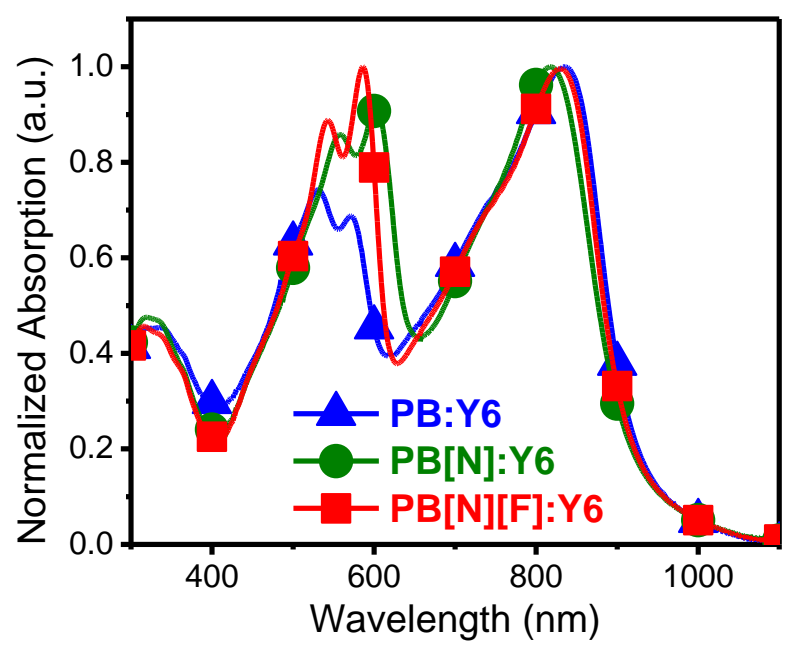

Figure S3. The normalized absorption spectra of the BHJ blend films fabricated from the corresponding polymer donors and Y6 acceptor (model system), polymer donor:Y6 = 1:1.2, wt/wt.

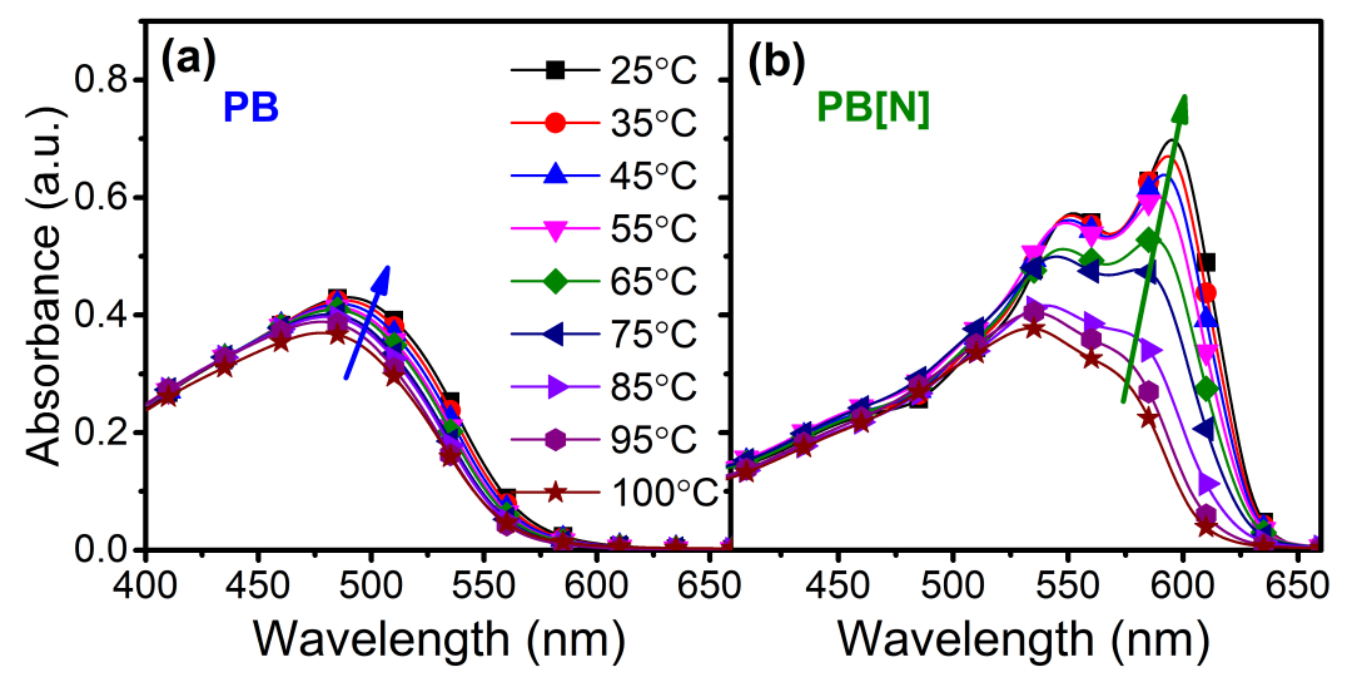

Figure S4. Temperature dependent UV-vis absorption spectra of (a) $\mathrm{PB}$ and (b) $\mathrm{PB}[\mathrm{N}]$ in chlorobenzene (repeat unit concentration ca. $1 \times 10^{-5} \mathrm{M}$ ) ${ }^{1}$. Reprinted with permission from the publisher. Copyright @ 2019, American Chemical Society 


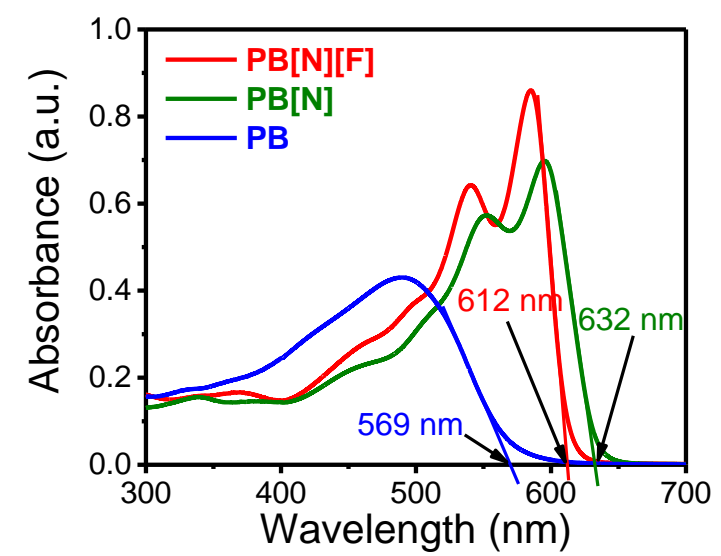

Figure S5. Determination of absorption edges of $\mathrm{PB}, \mathrm{PB}[\mathrm{N}]$ and $\mathrm{PB}[\mathrm{N}][\mathrm{F}]$ in chlorobenzene (repeat unit concentration ca. $1 \times 10^{-5} \mathrm{M}, 25^{\circ} \mathrm{C}$ ).

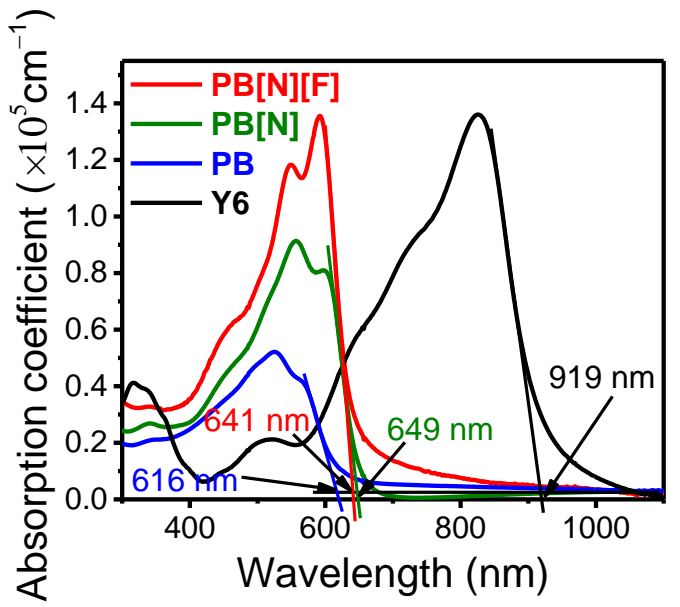

Figure S6. Determination of absorption edges of $\mathrm{PB}, \mathrm{PB}[\mathrm{N}], \mathrm{PB}[\mathrm{N}][\mathrm{F}]$ and $\mathrm{Y} 6$ in thin films. 
Table S1. Optical and Electronic Parameters of PB, PB[N], PB[N][F], and Y6 $\left(25^{\circ} \mathrm{C}\right)$

\begin{tabular}{|c|c|c|c|c|c|c|c|}
\hline \multirow[b]{2}{*}{ Material } & \multicolumn{2}{|c|}{ Solution $^{a}$} & \multicolumn{2}{|c|}{ Film } & \multirow{2}{*}{$\begin{array}{c}E_{\mathrm{g}}^{\mathrm{opt}} \\
(\mathrm{eV})^{b}\end{array}$} & \multirow{2}{*}{$\begin{array}{c}\text { IP } \\
(\mathrm{eV})^{c}\end{array}$} & \multirow{2}{*}{$\begin{array}{c}\mathrm{EA} \\
(\mathrm{eV})^{d}\end{array}$} \\
\hline & $\begin{array}{l}\lambda_{\max } \\
(\mathrm{nm})\end{array}$ & $\begin{array}{l}\lambda_{\text {onset }} \\
(\mathrm{nm})\end{array}$ & $\begin{array}{l}\lambda_{\max } \\
(\mathrm{nm})\end{array}$ & $\begin{array}{l}\lambda_{\text {onset }} \\
(\mathrm{nm})\end{array}$ & & & \\
\hline PB & 490 & 569 & 525 & 616 & 2.01 & 5.05 & 3.04 \\
\hline $\mathrm{PB}[\mathrm{N}]$ & 553,595 & 632 & 557,598 & 649 & 1.91 & 5.20 & 3.29 \\
\hline $\mathrm{PB}[\mathrm{N}][\mathrm{F}]$ & 540,585 & 612 & 550,592 & 641 & 1.93 & 5.25 & 3.32 \\
\hline Y6 & N/A & N/A & 826 & 919 & 1.35 & 5.63 & 4.28 \\
\hline
\end{tabular}

${ }^{a}$ In chlorobenzene at room temperature $\left(25^{\circ} \mathrm{C}\right)$.

${ }^{b} E=h c / \lambda=h(\mathrm{~J} \cdot \mathrm{s}) \cdot c\left(\mathrm{~m} \cdot \mathrm{s}^{-1}\right) / \lambda(\mathrm{nm})=h(\mathrm{C} \cdot \mathrm{V} \cdot \mathrm{s}) \cdot c \times 10^{9}\left(\mathrm{~nm} \cdot \mathrm{s}^{-1}\right) / \lambda(\mathrm{nm})=\left(h c \times 10^{9} / q\right) / \lambda(\mathrm{eV})$, where $h$ is the Plank constant, $h=6.63 \times 10^{-34} \mathrm{~J} \cdot \mathrm{s}, c$ is the speed of light in vacuum, $c=3.00 \times 10^{8} \mathrm{~m} \cdot \mathrm{s}^{-1}, q$ is the elementary charge, $q=1.60 \times 10^{-19} \mathrm{C}$, note that the unit of wavelength $\lambda$ is $\mathrm{nm}$ in the final equation. Thus $E_{\mathrm{g}}{ }^{\text {opt }}=1240 / \lambda_{\text {onset }}(\mathrm{eV})($ film).

${ }^{c}$ Estimated by photoelectron spectroscopy in air (PESA).

${ }^{d} \mathrm{EA}=\mathrm{IP}-E_{\mathrm{g}}{ }^{\mathrm{opt}}$. 


\section{Additional Data for nonfullerene PSCs and device optimization.}

\subsection{Statistical information of the nonfullerene PSCs.}

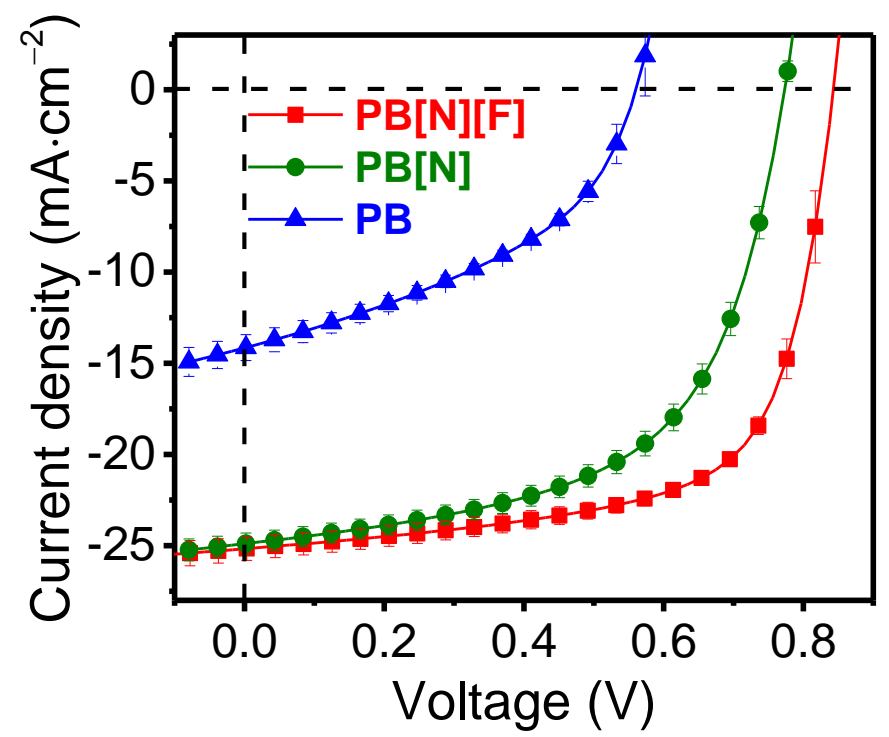

Figure S7. $J-V$ curve statistics of the BHJ solar cells. Device performance of the polymer donors $(\mathrm{PB}, \mathrm{PB}[\mathrm{N}]$ and $\mathrm{PB}[\mathrm{N}][\mathrm{F}]$ ) in conventional $\mathrm{BHJ}$ solar cells with $\mathrm{Y} 6$ as acceptor (model system); measurements under AM $1.5 \mathrm{G}\left(100 \mathrm{~mW} \mathrm{~cm}^{-2}\right)$. For each system, the markers denote the average values and error bars show the high and low values across >10 devices. Standard deviations calculated with the following Equation (1):

$$
\sigma=\sqrt{\frac{1}{N} \sum_{i=1}^{N}\left(x_{i}-\mu\right)^{2}}
$$

where $\sigma$ is the standard deviation, $\mu$ is the arithmetic average value of the devices' parameters, $\mathrm{N}$ is the total number of devices used in the determination of the standard deviations. 
Table S2. Statistical Photovoltaic Parameters of PB:Y6, PB[N]:Y6 and PB[N][F]:Y6 Based Devices.

\begin{tabular}{ccccc} 
Material & $V_{\mathrm{OC}}(\mathrm{V})$ & $J_{\mathrm{SC}}\left(\mathrm{mA} \mathrm{cm}^{-2}\right)$ & $\mathrm{FF}(\%)$ & ${\text { average PCE }(\%)^{a}}^{a}$ \\
$\mathrm{~PB}[\mathrm{~N}][\mathrm{F}]$ & $0.844 \pm 0.008$ & $25.17 \pm 0.65$ & $66.5 \pm 1.4$ & $14.11 \pm 0.14$ \\
$\mathrm{~PB}[\mathrm{~N}]$ & $0.773 \pm 0.002$ & $24.89 \pm 0.58$ & $57.9 \pm 1.1$ & $11.15 \pm 0.40$ \\
$\mathrm{~PB}$ & $0.563 \pm 0.014$ & $14.16 \pm 0.71$ & $42.5 \pm 1.3$ & $3.38 \pm 0.10$ \\
\multicolumn{2}{l}{${ }^{a}$ Average values were obtained from at least 10 devices. (device area [mask]: $0.04 \mathrm{~cm}^{2}$ ) }
\end{tabular}

\subsection{Comparison of measured $J_{\mathrm{SC}}$ and integrated $J_{\mathrm{SC}}$ from $\mathrm{EQE}$ measurements}

Table S3. Comparison of measured $J_{\mathrm{SC}}$ and integrated $J_{\mathrm{SC}}$ from EQE measurements

\begin{tabular}{cccc|}
\hline Material & $\begin{array}{c}J_{\mathrm{SC}}\left(\mathrm{mA} \mathrm{cm}^{-2}\right) \\
\text { extracted from } J-V \text { curves }\end{array}$ & $\begin{array}{c}J_{\mathrm{SC}}\left(\mathrm{mA} \mathrm{cm}^{-2}\right) \\
\text { calculated from EQE }\end{array}$ & Error $(\%)$ \\
\hline $\mathrm{PB}[\mathrm{N}][\mathrm{F}]$ & 24.94 & 24.52 & 1.68 \\
$\mathrm{~PB}[\mathrm{~N}]$ & 25.51 & 24.77 & 2.90 \\
$\mathrm{~PB}$ & 14.55 & 14.26 & 1.99 \\
\hline
\end{tabular}

\subsection{Device performance optimization of $\mathrm{PB}[\mathrm{N}][\mathrm{F}]$ :Y6 based solar cells}

Table S4. Photovoltaic parameters of BHJ solar cells with different processing solvents

$\begin{array}{ccccc}\text { Processing solvent and additive } & \begin{array}{c}V_{\mathrm{OC}} \\ \text { (V) }\end{array} & \begin{array}{c}J_{\mathrm{SC}} \\ \left(\mathrm{mA} \cdot \mathrm{cm}^{-2}\right)\end{array} & \begin{array}{c}\text { Fill Factor } \\ (\%)\end{array} & \begin{array}{c}\text { Efficiency } \\ (\%)\end{array} \\ \text { CF w/o additive }{ }^{a} & 0.84 & 22.7 & 55.3 & 10.5(9.8 \pm 0.6) \\ \mathrm{CF} \text { w/ 0.5 vol\% } \mathrm{DIO}^{b} & 0.85 & 23.7 & 67.6 & 13.7(13.1 \pm 0.3) \\ \mathrm{CF} \text { w } 0.5 \mathrm{vol} \% \mathrm{CN}^{c} & 0.86 & 24.6 & 57.3 & 12.1(11.7 \pm 0.4) \\ \mathrm{CB} \text { w/ } 0.5 \text { vol\% CN }{ }^{d} & 0.80 & 17.7 & 67.6 & 9.5(8.9 \pm 0.4) \\ { }^{a} \mathrm{CF} \text { : chloroform. } & & & & \\ { }^{b} \mathrm{DIO}: \text { 1,8-diiodooctane. } & & & & \\ { }^{c} \mathrm{CN} \text { : } 1 \text {-Chloronaphthalene. } & & & & \\ { }^{d} \mathrm{CB} \text { : chlorobenzene. } & & & & \end{array}$


Table S5. Photovoltaic parameters of BHJ solar cells with varied D:A ratios

$\begin{array}{ccccc}\begin{array}{c}\text { Donor:Acceptor } \\ (\mathrm{wt} / \mathrm{wt})\end{array} & \begin{array}{c}V_{\mathrm{OC}} \\ (\mathrm{V})\end{array} & \begin{array}{c}J_{\mathrm{SC}} \\ \left(\mathrm{mA} \cdot \mathrm{cm}^{-2}\right)\end{array} & \begin{array}{c}\text { Fill Factor } \\ (\%)\end{array} & \begin{array}{c}\text { Efficiency } \\ (\%)\end{array} \\ 1.2: 1 & 0.84 & 22.4 & 49.4 & 9.2(8.7 \pm 0.3) \\ 1: 1 & 0.85 & 23.5 & 61.9 & 12.3(11.9 \pm 0.3) \\ \mathbf{1 : 1 . 2} & \mathbf{0 . 8 3} & \mathbf{2 3 . 8} & \mathbf{6 2 . 9} & \mathbf{1 2 . 5}(\mathbf{1 2 . 0} \pm \mathbf{0 . 3}) \\ 1: 1.5 & 0.84 & 22.8 & 62.3 & 11.9(11.6 \pm 0.3)\end{array}$

Table S6. Photovoltaic parameters of BHJ solar cells with varied thermal annealing (TA) temperatures (active layer processed with $\mathrm{CF}$ w/ 0.5 vol\% DIO)

$\begin{array}{ccccc}\begin{array}{c}\text { TA temperature } \\ \left({ }^{\circ} \mathrm{C}\right)\end{array} & \begin{array}{c}V_{\mathrm{OC}} \\ (\mathrm{V})\end{array} & \begin{array}{c}J_{\mathrm{SC}} \\ \left(\mathrm{mA} \cdot \mathrm{cm}^{-2}\right)\end{array} & \begin{array}{c}\text { Fill Factor } \\ (\%)\end{array} & \begin{array}{c}\text { Efficiency } \\ (\%)\end{array} \\ \text { as-cast } & \mathbf{0 . 8 5} & \mathbf{2 3 . 7} & \mathbf{6 7 . 6} & \mathbf{1 3 . 7}(\mathbf{1 3 . 1} \pm \mathbf{0 . 3}) \\ 90 & 0.83 & 24.0 & 62.8 & 12.5(12.3 \pm 0.1) \\ 110 & 0.83 & 24.2 & 62.5 & 12.5(12.4 \pm 0.1) \\ 130 & 0.83 & 23.9 & 60.3 & 12.0(11.6 \pm 0.4)\end{array}$

Table S7. Photovoltaic parameters of BHJ solar cells processed with varied additives

\begin{tabular}{c|c|c|c|c|c}
\multicolumn{2}{c|}{$\begin{array}{c}\text { Additive } \\
\text { (vol\% in CF) }\end{array}$} & $\begin{array}{c}V_{\mathrm{OC}} \\
(\mathrm{V})\end{array}$ & $\begin{array}{c}J_{\mathrm{SC}} \\
\left(\mathrm{mA} \cdot \mathrm{cm}^{-2}\right)\end{array}$ & $\begin{array}{c}\text { Fill Factor } \\
(\%)\end{array}$ & $\begin{array}{c}\text { Efficiency } \\
(\%)\end{array}$ \\
\hline \multicolumn{2}{c}{ w/o additive } & 0.84 & 22.7 & 55.3 & $10.5(9.8 \pm 0.6)$ \\
\hline \multirow{3}{*}{ DIO $^{a}$} & 0.25 & 0.86 & 24.7 & 59.8 & $12.6(11.7 \pm 0.5)$ \\
\cline { 2 - 6 } & 0.5 & 0.85 & 23.7 & 67.6 & $13.7(13.1 \pm 0.3)$ \\
\cline { 2 - 6 } & 1.0 & 0.84 & 24.0 & 64.7 & $13.0(12.5 \pm 0.4)$ \\
\hline \multirow{3}{*}{ DPE $^{b}$} & 0.5 & 0.86 & 25.0 & 64.9 & $13.9(13.0 \pm 0.5)$ \\
\cline { 2 - 6 } & $\mathbf{1 . 0}$ & $\mathbf{0 . 8 5}$ & $\mathbf{2 5 . 3}$ & $\mathbf{6 4 . 5}$ & $\mathbf{1 3 . 9}(\mathbf{1 3 . 4} \pm \mathbf{0 . 3})$ \\
\cline { 2 - 6 } & 2.0 & 0.83 & 24.9 & 65.1 & $13.5(12.7 \pm 0.6)$ \\
\hline \multirow{3}{*}{$\mathrm{DBE}^{c}$} & 0.6 & 0.84 & 25.4 & 64.8 & $13.8(13.1 \pm 0.7)$ \\
\cline { 2 - 6 } & 1.0 & 0.82 & 22.6 & 68.6 & $12.8(12.5 \pm 0.1)$ \\
\hline
\end{tabular}

${ }^{a}$ DIO: 1,8 -diiodooctane.

${ }^{b}$ DPE: diphenyl ether.

${ }^{c}$ DBE: dibenzyl ether. 
Table S8. Photovoltaic Parameters of BHJ solar cells Processed with Solvent Vapor Annealing (SVA)

\begin{tabular}{|c|c|c|c|c|c|c|}
\hline Additive & $\begin{array}{r}\text { Solvent } \\
\text { for SVA }\end{array}$ & Time for SVA & $\begin{array}{l}V_{\mathrm{OC}} \\
(\mathrm{V})\end{array}$ & $\begin{array}{c}J_{\mathrm{SC}} \\
\left(\mathrm{mA} \cdot \mathrm{cm}^{-2}\right)\end{array}$ & $\begin{array}{l}\text { Fill Factor } \\
(\%)\end{array}$ & $\begin{array}{c}\text { Efficiency } \\
(\%)\end{array}$ \\
\hline \multirow{6}{*}{0.5 vol $\%$ DIO } & \multirow{3}{*}{$\mathbf{C S}_{\mathbf{2}}{ }^{a}$} & $40 \mathrm{~s}$ & 0.84 & 25.0 & 67.6 & $14.2(13.9 \pm 0.2)$ \\
\hline & & $100 \mathrm{~s}$ & 0.84 & 25.3 & 62.7 & $13.3(13.1 \pm 0.2)$ \\
\hline & & $240 \mathrm{~s}$ & 0.84 & 25.0 & 63.3 & $13.3(13.2 \pm 0.0)$ \\
\hline & \multirow{3}{*}{$\operatorname{DMDS}^{b}$} & $30 \mathrm{~s}$ & 0.84 & 23.8 & 64.7 & $12.9(12.6 \pm 0.2)$ \\
\hline & & $40 \mathrm{~s}$ & 0.84 & 24.4 & 63.4 & $13.0(12.9 \pm 0.1)$ \\
\hline & & $60 \mathrm{~s}$ & 0.85 & 24.1 & 61.0 & $12.5(12.3 \pm 0.2)$ \\
\hline 0.6 vol\% DBE & \multirow{5}{*}{$\mathbf{C S}_{2}$} & $40 \mathrm{~s}$ & 0.84 & 24.1 & 64.7 & $13.1(12.6 \pm 0.4)$ \\
\hline 1.0 vol\% DBE & & $40 \mathrm{~s}$ & 0.82 & 22.1 & 67.2 & $12.3(12.2 \pm 0.1)$ \\
\hline \multirow{2}{*}{1.0 vol\% DPE } & & $40 \mathrm{~s}$ & 0.85 & 24.9 & 68.1 & $14.4(14.1 \pm 0.1)$ \\
\hline & & $70 \mathrm{~s}$ & 0.84 & 26.5 & 59.9 & $13.4(12.7 \pm 0.5)$ \\
\hline 2.0 vol $\%$ DPE & & $40 \mathrm{~s}$ & 0.83 & 24.7 & 65.3 & $13.4(12.6 \pm 0.9)$ \\
\hline
\end{tabular}

${ }^{a} \mathrm{CS}_{2}$ : carbon disulfide.

${ }^{b}$ DMDS: dimethyl disulfide.

Table S9. Photovoltaic Parameters of BHJ solar cells Based on Inverted Structure

$\begin{array}{ccccc}\text { Electron transporting layer (ETL) } & \begin{array}{c}V_{\mathrm{OC}} \\ (\mathrm{V})\end{array} & \begin{array}{c}J_{\mathrm{SC}} \\ \left(\mathrm{mA} \cdot \mathrm{cm}^{-2}\right)\end{array} & \begin{array}{c}\text { Fill Factor } \\ (\%)\end{array} & \begin{array}{c}\text { Efficiency } \\ (\%)\end{array} \\ \text { ZnO/PDINO } & 0.87 & 22.2 & 64.0 & 12.3(11.4 \pm 0.7) \\ \mathrm{ZnO} & 0.85 & 21.5 & 64.4 & 11.7(11.0 \pm 0.4)\end{array}$

Inverted structure: ITO/ETL/active layer/ $/ \mathrm{MoO}_{3} / \mathrm{Ag}$ 


\section{Photoluminescent (PL) quenching}
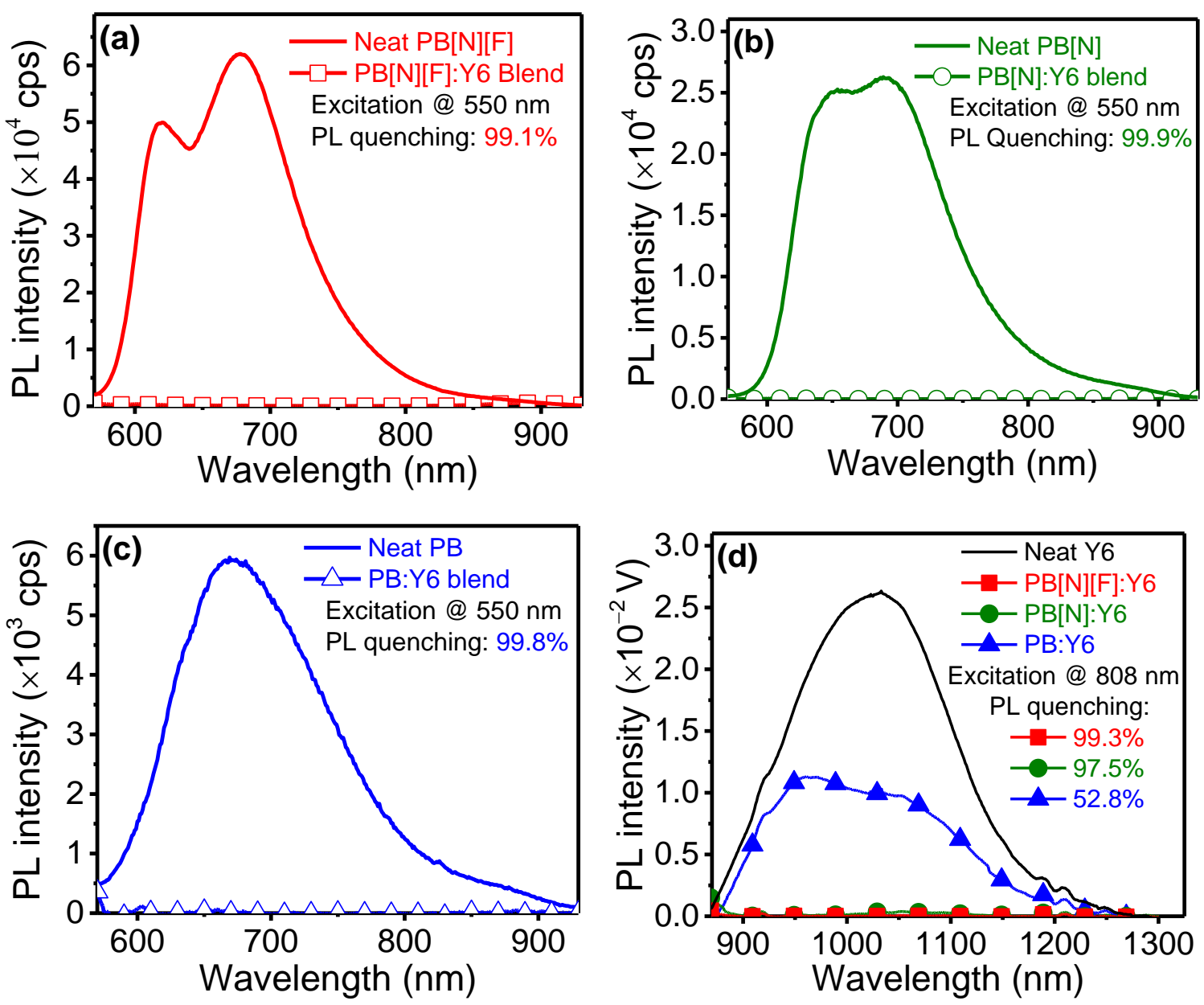

Figure S8. PL spectra of $\mathrm{PB}, \mathrm{PB}[\mathrm{N}], \mathrm{PB}[\mathrm{N}][\mathrm{F}]$ and $\mathrm{Y} 6$ neat films (solid lines), and the corresponding BHJ thin films in the presence of the acceptor/donor counterpart (symbol lines). (a) PB:Y6, excitation at $550 \mathrm{~nm}$; (b) $\mathrm{PB}[\mathrm{N}]: \mathrm{Y} 6$, excitation at $550 \mathrm{~nm}$; (c) $\mathrm{PB}[\mathrm{N}][\mathrm{F}]: \mathrm{Y} 6$, excitation at $550 \mathrm{~nm}$; (d) PB:Y6, PB[N]:Y6 and PB[N][F]:Y6, excitation at $808 \mathrm{~nm}$. 


\section{Space Charge Limited Current (SCLC) Measurements}

The hole mobility was measured using a hole-only device with the configuration of ITO/PEDOT:PSS $(40 \mathrm{~nm}) /$ active layer/ $\mathrm{MoO}_{3}(10 \mathrm{~nm}) / \mathrm{Ag}(100 \mathrm{~nm})$. The electron mobility was measured using an electron-only device with the configuration of ITO/ZnO (40 nm)/active layer/PDINO $(10 \mathrm{~nm}) / \mathrm{Ag}(100 \mathrm{~nm})$. The $\mathrm{ZnO}$ precursor sol-gel was obtained from stirring the solution of $1.0 \mathrm{~g} \mathrm{Zn}\left(\mathrm{CH}_{3} \mathrm{COO}\right)_{2} \cdot 2 \mathrm{H}_{2} \mathrm{O}$ in $10 \mathrm{~mL}$ ethylene glycol monomethyl ether and $275 \mu \mathrm{L}$ ethylenediamine at $50{ }^{\circ} \mathrm{C}$ for $12 \mathrm{~h}$. The $\mathrm{ZnO}$ films were prepared by spin-coating the $\mathrm{ZnO}$ precursor onto the UV-ozone-treated ITO substrates and then thermally annealing them at $200{ }^{\circ} \mathrm{C}$ for $1 \mathrm{~h}$ in atmosphere. The active layers were prepared following the same procedures used to fabricate the optimized photovoltaic devices.

The hole and electron mobilities were calculated by fitting the dark current to the model of a single-carrier space charge limited current (SCLC), which is described by the MOTT-Gurney Equation $(2)^{3-4}$ :

$$
J=\frac{9 \varepsilon_{0} \varepsilon_{\mathrm{r}} \mu V^{2}}{8 L^{3}}
$$

where $J$ is the current measured under dark condition for hole-only and electron-only devices, $\mu$ is the zero-filed mobility, and $\varepsilon_{0}$ is the vacuum permittivity $\left(\varepsilon_{0}=8.85 \mathrm{C} \cdot \mathrm{V}^{-1} \cdot \mathrm{s}^{-1}\right), \varepsilon_{\mathrm{r}}$ is the relative permittivity (for polymers, $\varepsilon_{\mathrm{r}}$ is assumed to be 3.0), $L$ is the thickness of the active layer. $V$ is the effective internal voltage, and $V=V_{\mathrm{appl}}-V_{\mathrm{bi}}-V_{\mathrm{s}}, V_{\text {appl }}$ is the applied voltage, $V_{\mathrm{bi}}$ is the built-in voltage induced by the work function difference of the two electrodes and Vs is the voltage drop from the substrate's series resistance (for electron-only device, $V_{\mathrm{s}}=0 \mathrm{~V}$, while for hole-only device, the series resistance is assumed to be $10 \Omega$ which is caused by $\mathrm{MoO}_{3}$ layer). Then the mobilities can be extracted from the slope of the $J^{1 / 2}-V$ curves by the Equation (3):

$$
\mu=\frac{\text { slope }^{2} \times 8 L^{3}}{9 \varepsilon_{0} \varepsilon_{\mathrm{r}}}
$$




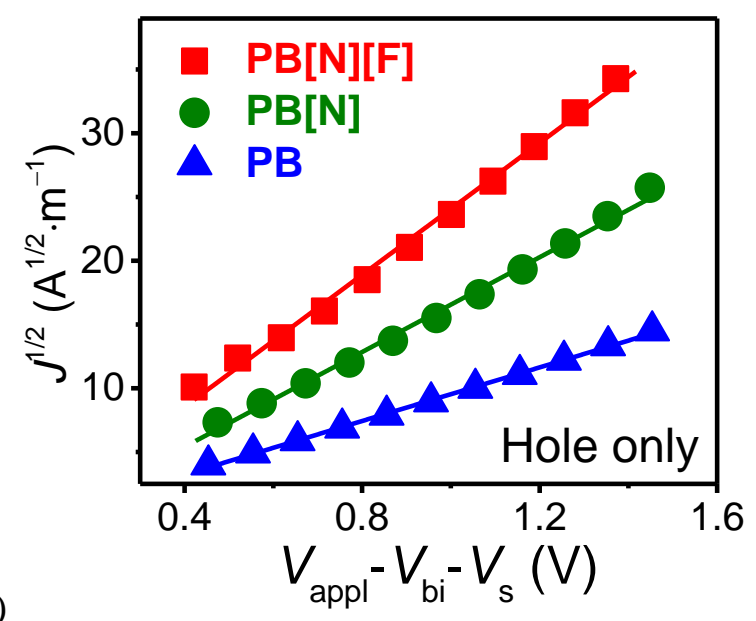

(a)

Figure S9. Dark $J-V$ characteristics of (a) hole-only and (b) electron-only diodes made with nonfullerene $\mathrm{BHJ}$ thin films composed of $\mathrm{PB}, \mathrm{PB}[\mathrm{N}]$ and $\mathrm{PB}[\mathrm{N}][\mathrm{F}]$ as polymer donors, and $\mathrm{Y} 6$ as polymer acceptor. The experimental data are fitted using the single-carrier SCLC model (solid lines).

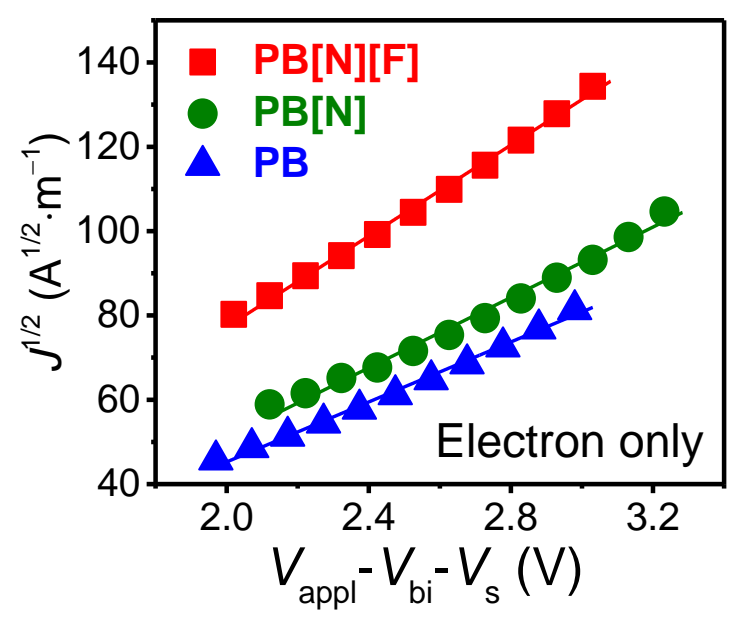

(b) 


\section{Additional morphology characterization data}

\subsection{Atomic Force Microscope images}
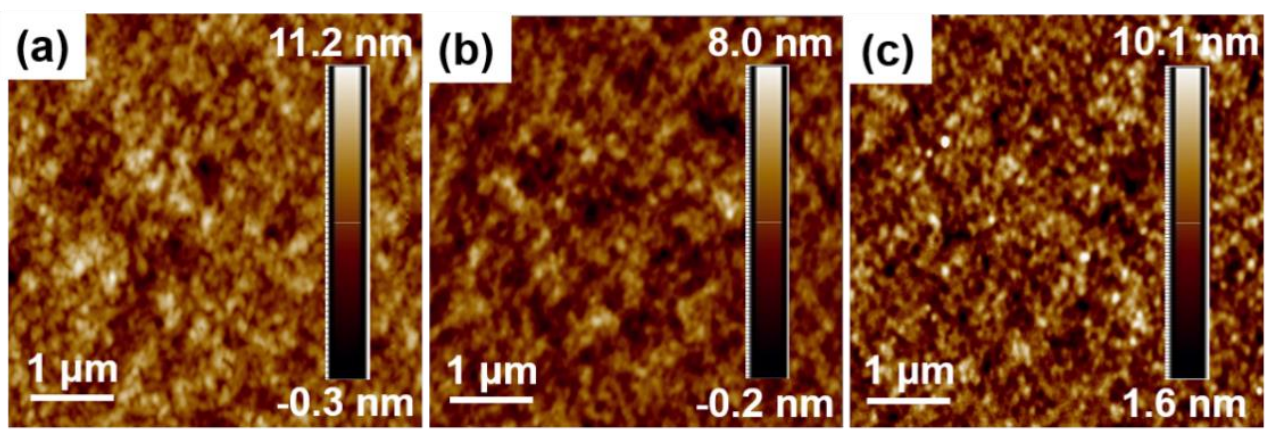

Figure S10. AFM height images of (a) PB:Y6 (Root-mean square (RMS) roughness: $1.327 \mathrm{~nm}$ ), (b) $\mathrm{PB}[\mathrm{N}]: \mathrm{Y} 6$ (RMS roughness: $0.952 \mathrm{~nm}$ ) and (c) PB[N][F]:Y6 (RMS roughness: $1.343 \mathrm{~nm}$ ) blends. 


\subsection{Additional GIWAXS patterns and summarized parameters}

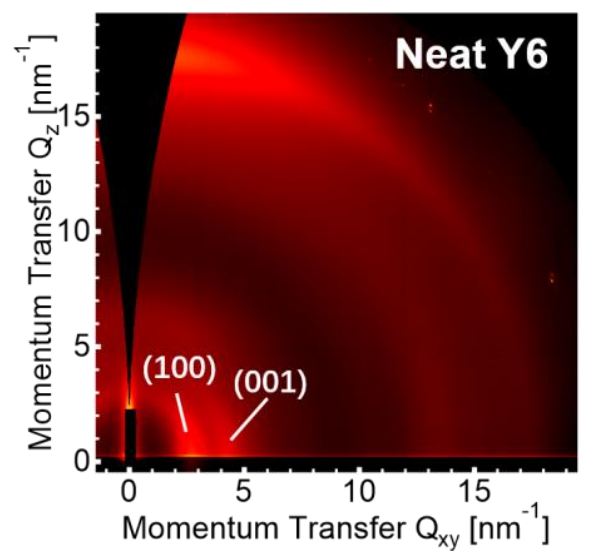

Figure S11. Two-dimentional (2D) GIWAXS pattern for neat Y6 film.

Table S10. Summarized GIWAXS Characteristics of Different Films.

\begin{tabular}{|c|c|c|c|c|c|c|c|}
\hline & & out-of-plane & out-of-plane & in-plane & $\begin{array}{c}\text { in-plane } \\
\text { (200) }\end{array}$ & $\begin{array}{c}\text { in-plane } \\
(300)\end{array}$ & $\begin{array}{c}\text { in-plane } \\
(001)\end{array}$ \\
\hline material & $\begin{array}{c}\text { out-of-plane } \\
\text { (010) Peak } \\
\text { Position } \\
\left(\AA^{-1}\right)\end{array}$ & $\begin{array}{c}(100) \text { Peak } \\
\text { Position } \\
\left(\AA^{-1}\right)\end{array}$ & $\begin{array}{c}\text { (200) Peak } \\
\text { Position } \\
\left(\AA^{-1}\right)\end{array}$ & $\begin{array}{c}(100) /(100)^{\prime} \\
\text { Peak Position } \\
\left(\AA^{-1}\right)\end{array}$ & $\begin{array}{c}\text { Peak } \\
\text { Position } \\
\left(\AA^{-1}\right)\end{array}$ & $\begin{array}{c}\text { Peak } \\
\text { Position } \\
\left(\AA^{-1}\right)\end{array}$ & $\begin{array}{c}\text { Peak } \\
\text { Position } \\
\left(\AA^{-1}\right)\end{array}$ \\
\hline Y6 & 1.77 & -- & -- & $0.28 / 0.42$ & -- & -- & -- \\
\hline PB & -- & -- & -- & 0.28 & -- & -- & -- \\
\hline $\mathrm{PB}[\mathrm{N}]$ & 1.70 & -- & -- & 0.29 & 0.63 & 0.95 & -- \\
\hline $\mathrm{PB}[\mathrm{N}][\mathrm{F}]$ & 1.70 & -- & -- & 0.29 & 0.62 & 0.94 & -- \\
\hline PB:Y6 & 1.77 & 0.34 & 0.66 & $0.28 / 0.42$ & -- & -- & 0.69 \\
\hline $\mathrm{PB}[\mathrm{N}]: \mathrm{Y} 6$ & 1.76 & -- & -- & $0.28 / 0.42$ & -- & -- & -- \\
\hline $\mathrm{PB}[\mathrm{N}][\mathrm{F}]: \mathrm{Y} 6$ & 1.76 & -- & -- & $0.28 / 0.42$ & 0.62 & -- & -- \\
\hline
\end{tabular}



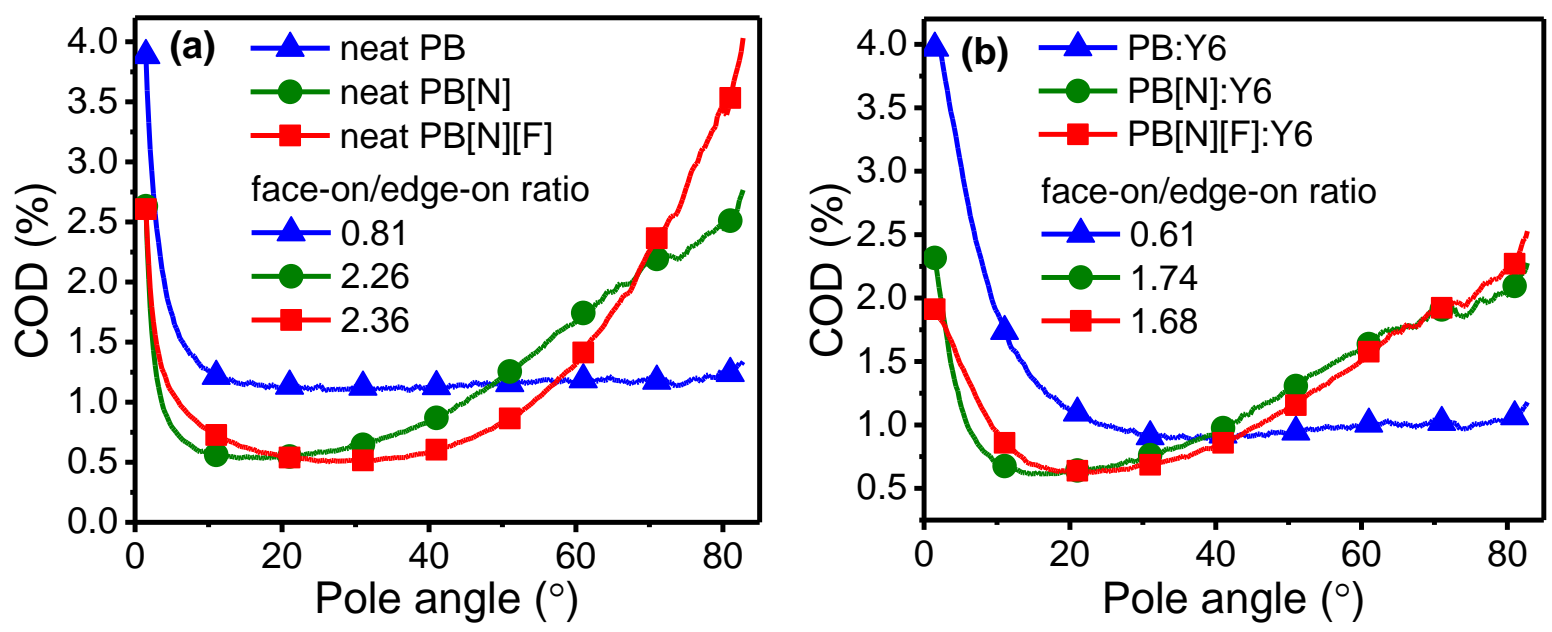

Figure S12 Crystallite orientation distribution (COD) functions for (a) neat $\mathrm{PB}$, neat $\mathrm{PB}[\mathrm{N}]$, neat $\mathrm{PB}[\mathrm{N}][\mathrm{F}]$, and (b) their blends with $\mathrm{Y} 6$, respectively. The neat $\mathrm{PB}[\mathrm{N}]$ film, neat $\mathrm{PB}[\mathrm{N}][\mathrm{F}]$ film and their BHJ films with Y6 have primarily face-on oriented crystallites with respect to the substrate.

The crystallite orientation distribution (COD) profiles were extracted from the circular line cut across (200). Pole angle $\chi$ ranging from $0^{\circ}$ to $90^{\circ}\left(0^{\circ}\right.$ denotes the direction perpendicular to the substrate) was chosen. The crystallite population was calculated by normalizing the measured diffraction intensity by the integrated total intensity within the pole angle range of interest with the assumption that crystallites from the same crystallographic direction at different pole angles are formed with similar crystallite thickness and lattice disorder.

The face-on/edge-on ratio can be calculated from the following equation ${ }^{5}$ :

$$
\text { face - on/edge - on ratio }=\frac{\int_{\pi / 4}^{\pi / 2} I(\chi) d \chi}{\int_{0}^{\pi / 4} I(\chi) d \chi}
$$




\section{Solution NMR Spectra}

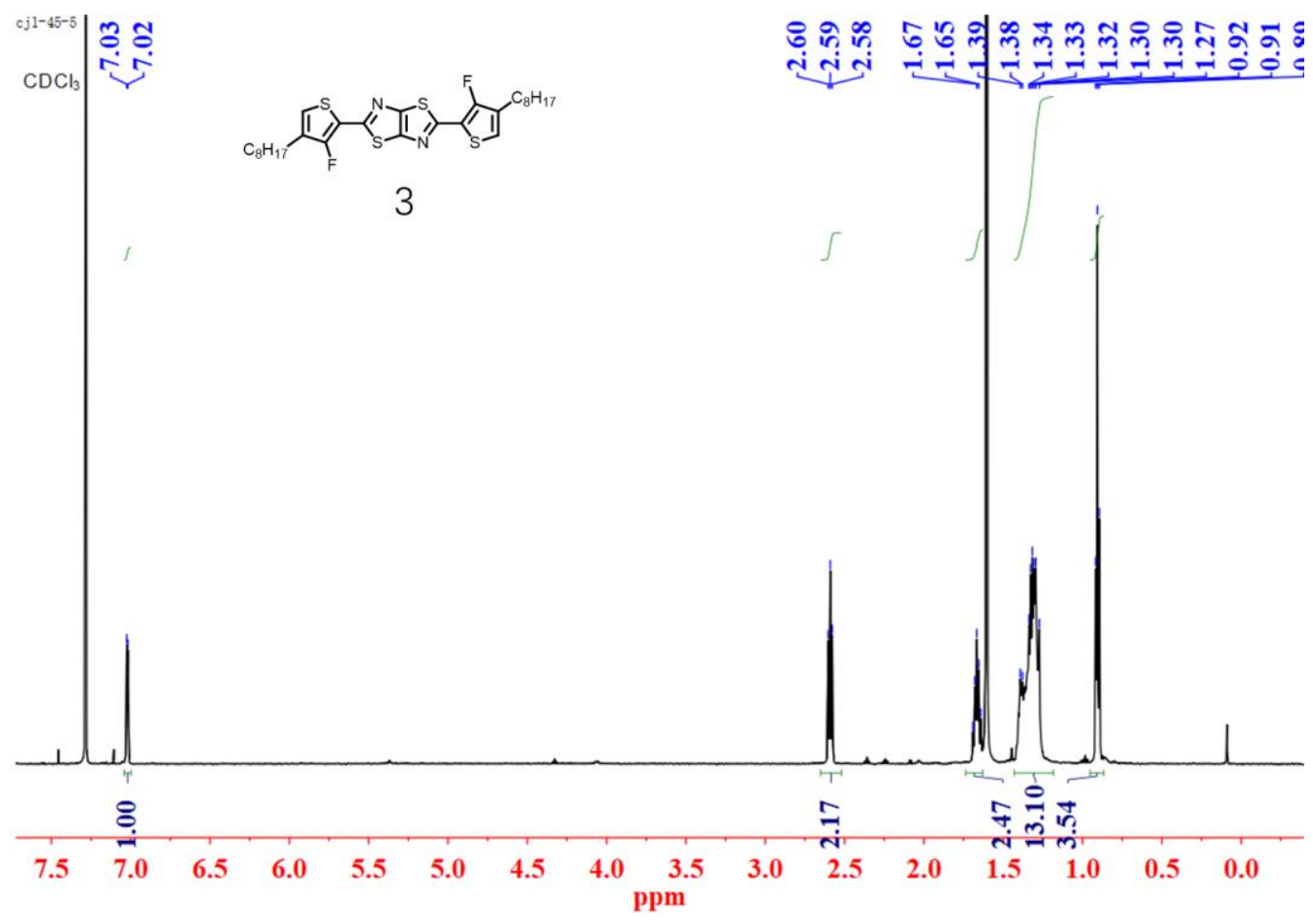

Figure S13. ${ }^{1} \mathrm{H}$ NMR spectrum of Compound 3 in $\mathrm{CDCl}_{3}$

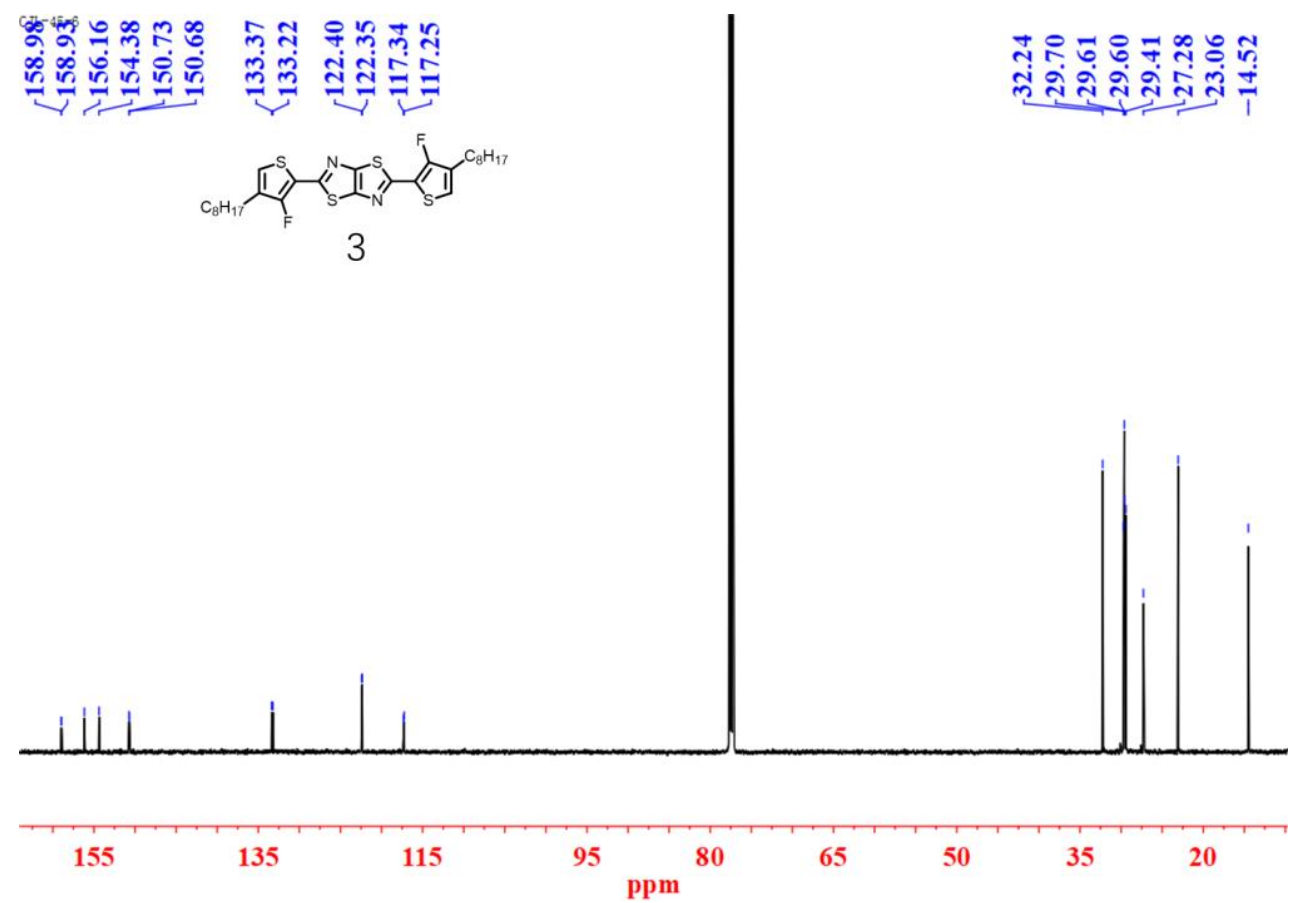

Figure S14. ${ }^{13} \mathrm{C}$ NMR spectrum of Compound 3 in $\mathrm{CDCl}_{3}$ 

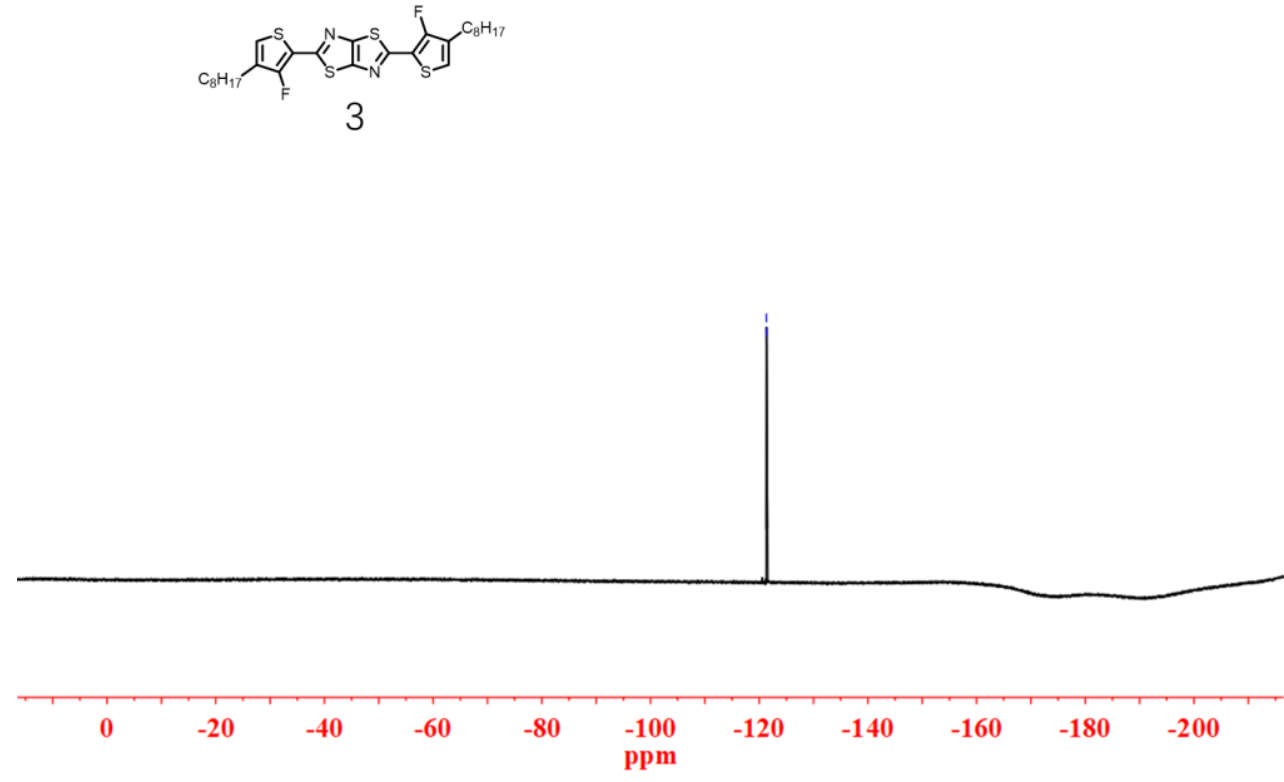

Figure S15. ${ }^{19} \mathrm{~F}$ NMR spectrum of Compound 3 in $\mathrm{CDCl}_{3}$

CJI-50
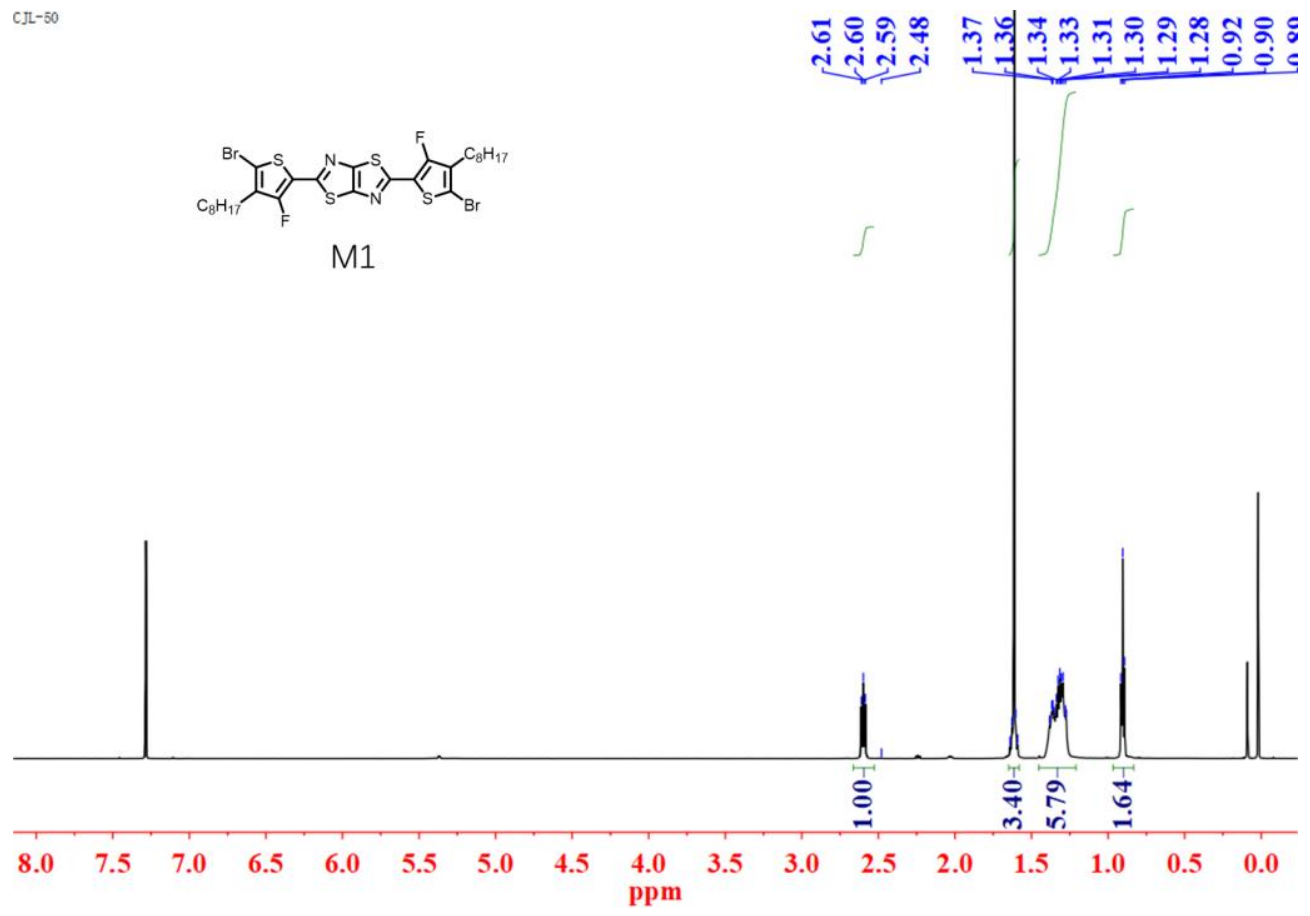

Figure S16. ${ }^{1} \mathrm{H}$ NMR spectrum of Compound $\mathbf{M 1}$ in $\mathrm{CDCl}_{3}$ 


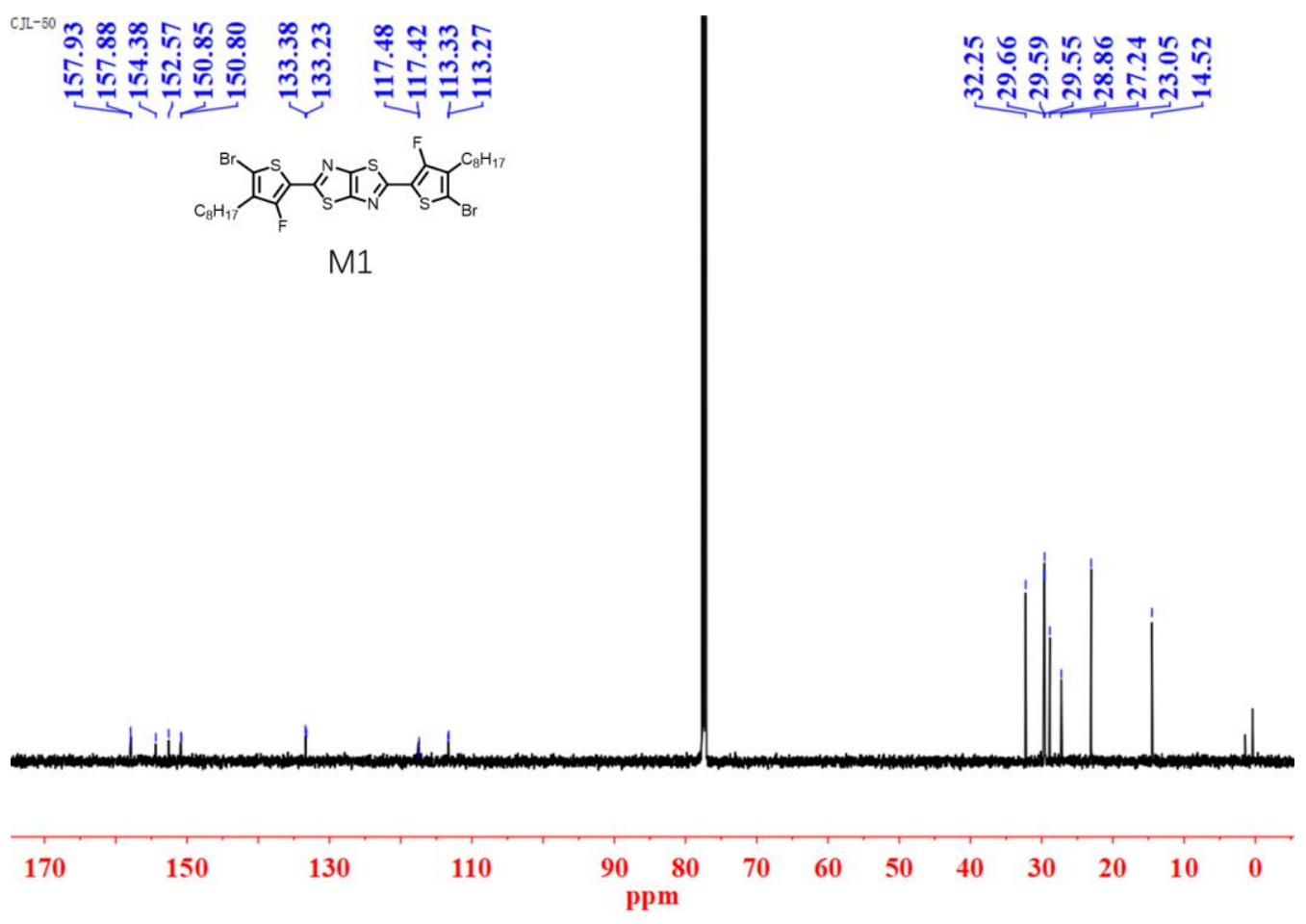

Figure S17. ${ }^{13} \mathrm{C}$ NMR spectrum of Compound $\mathbf{M 1}$ in $\mathrm{CDCl}_{3}$

F橎

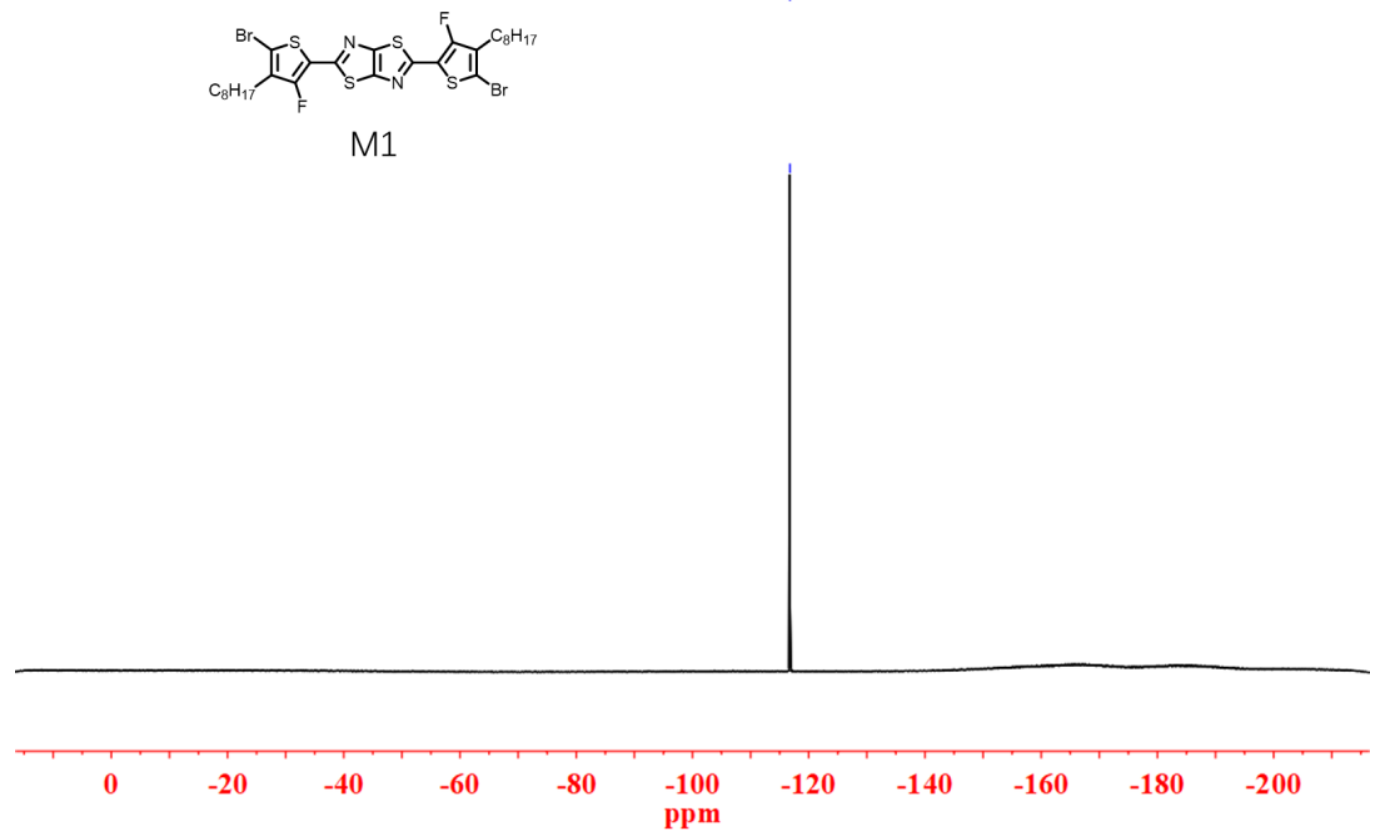

Figure S18. ${ }^{19} \mathrm{~F}$ NMR spectrum of Compound $\mathrm{M1}$ in $\mathrm{CDCl}_{3}$ 


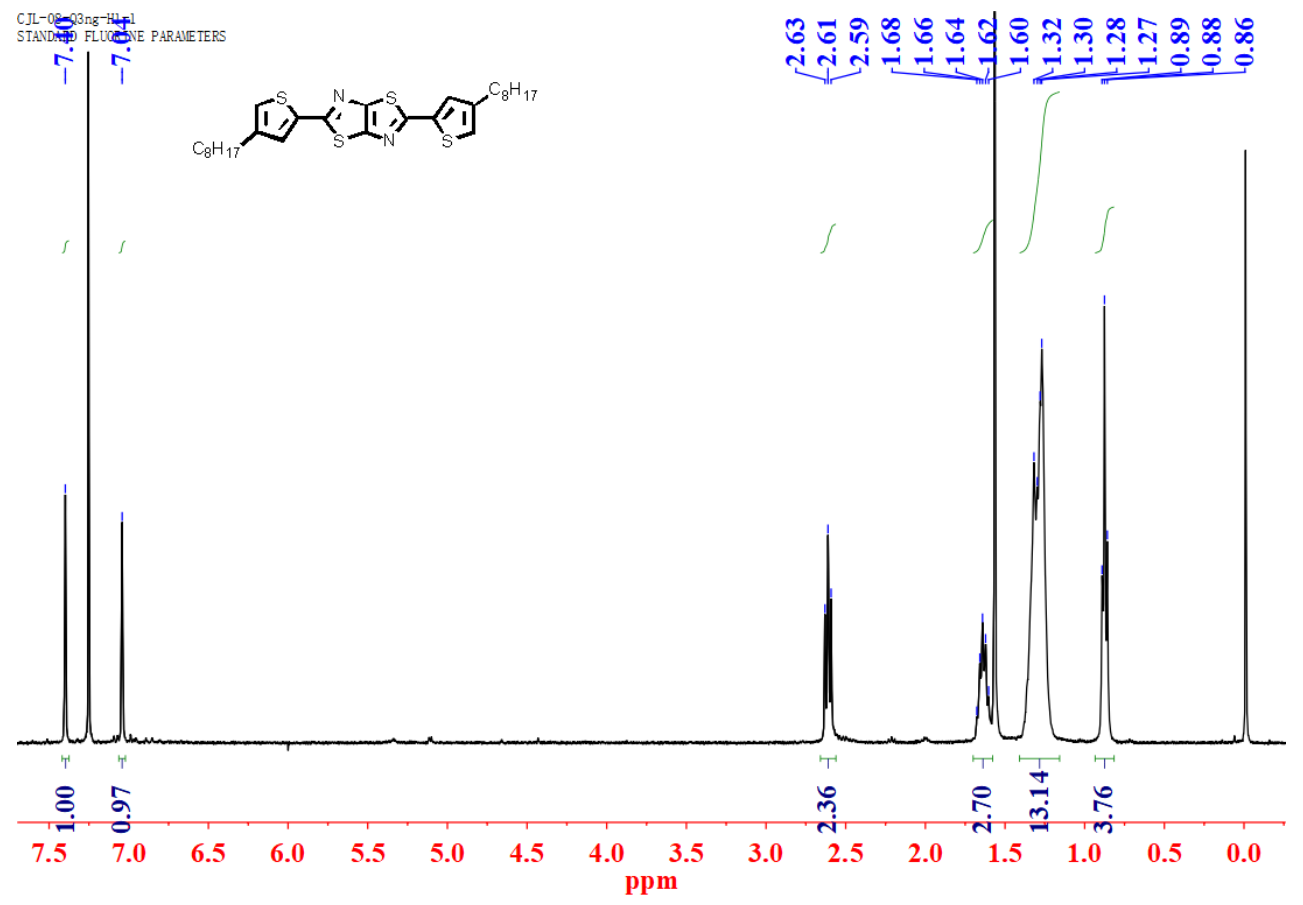

Figure S19. ${ }^{1} \mathrm{H}$ NMR spectrum of Compound $5^{1}$. Reprinted with permission from the publisher. Copyright (C) 2019, American Chemical Society

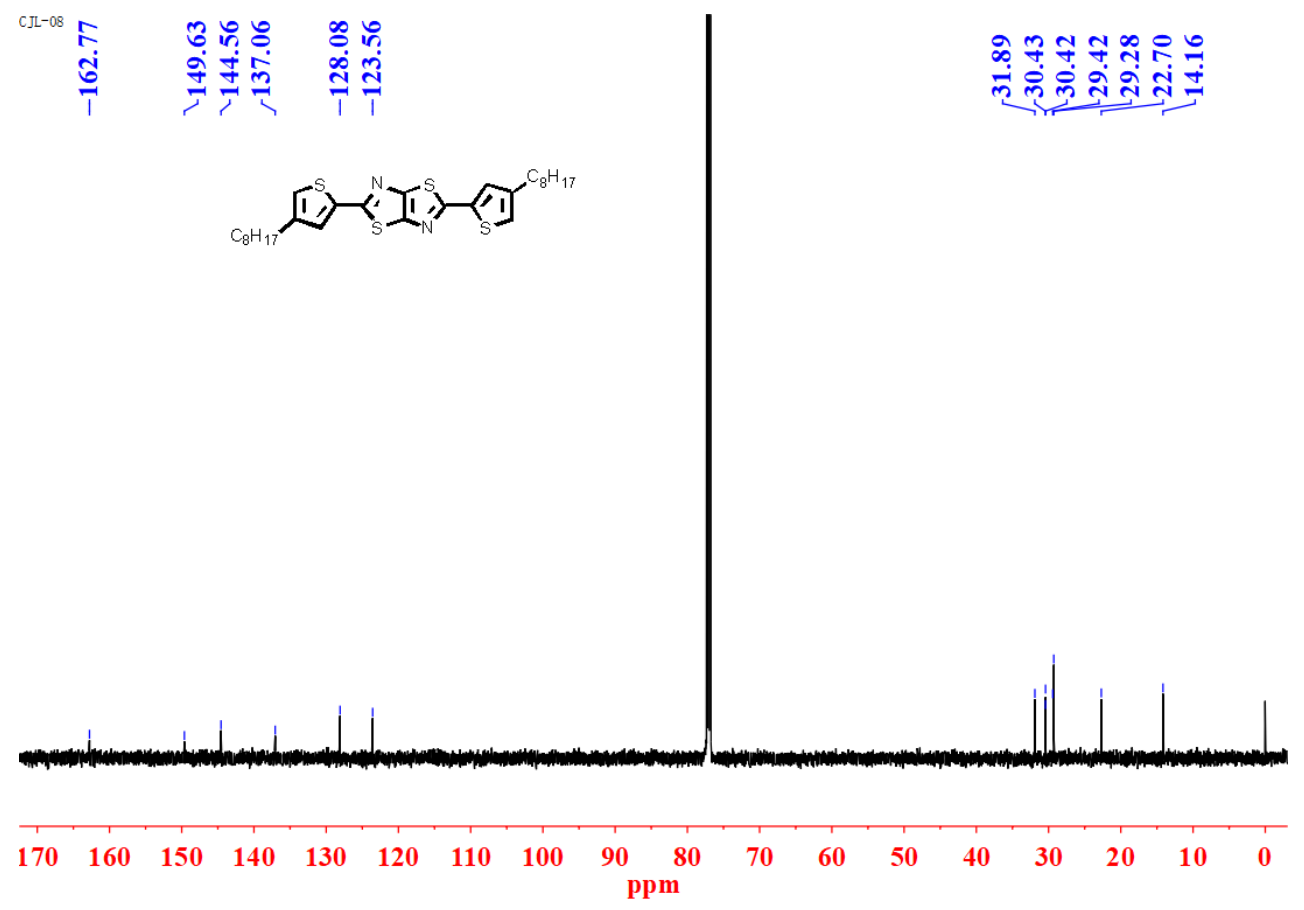

Figure S20. ${ }^{13} \mathrm{C}$ NMR spectrum of Compound $\mathbf{5}^{1}$. Reprinted with permission from the publisher. Copyright (C) 2019, American Chemical Society 


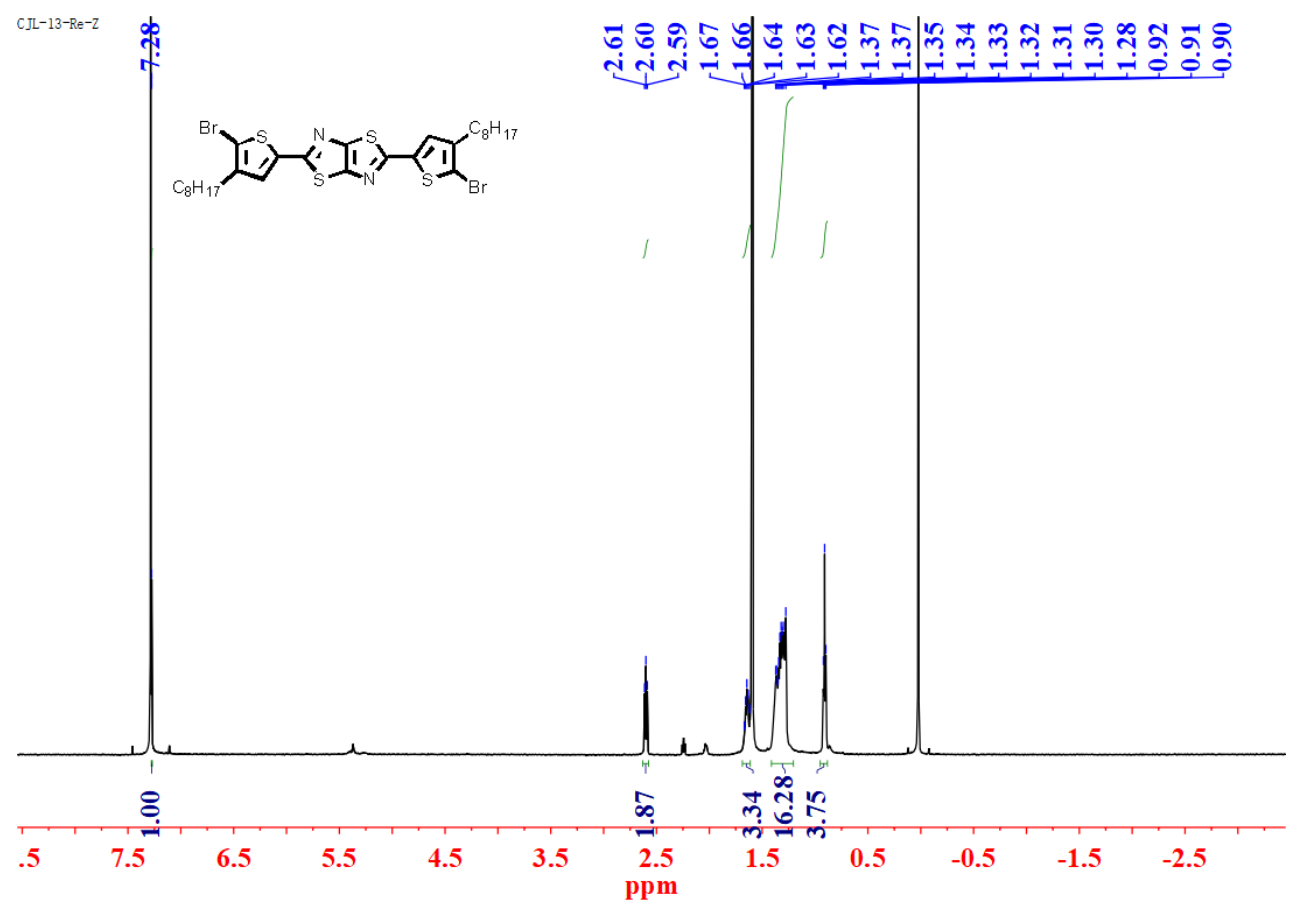

Figure S21. ${ }^{1} \mathrm{H}$ NMR spectrum of Compound $\mathbf{M 3}{ }^{1}$. Reprinted with permission from the publisher. Copyright (C 2019, American Chemical Society

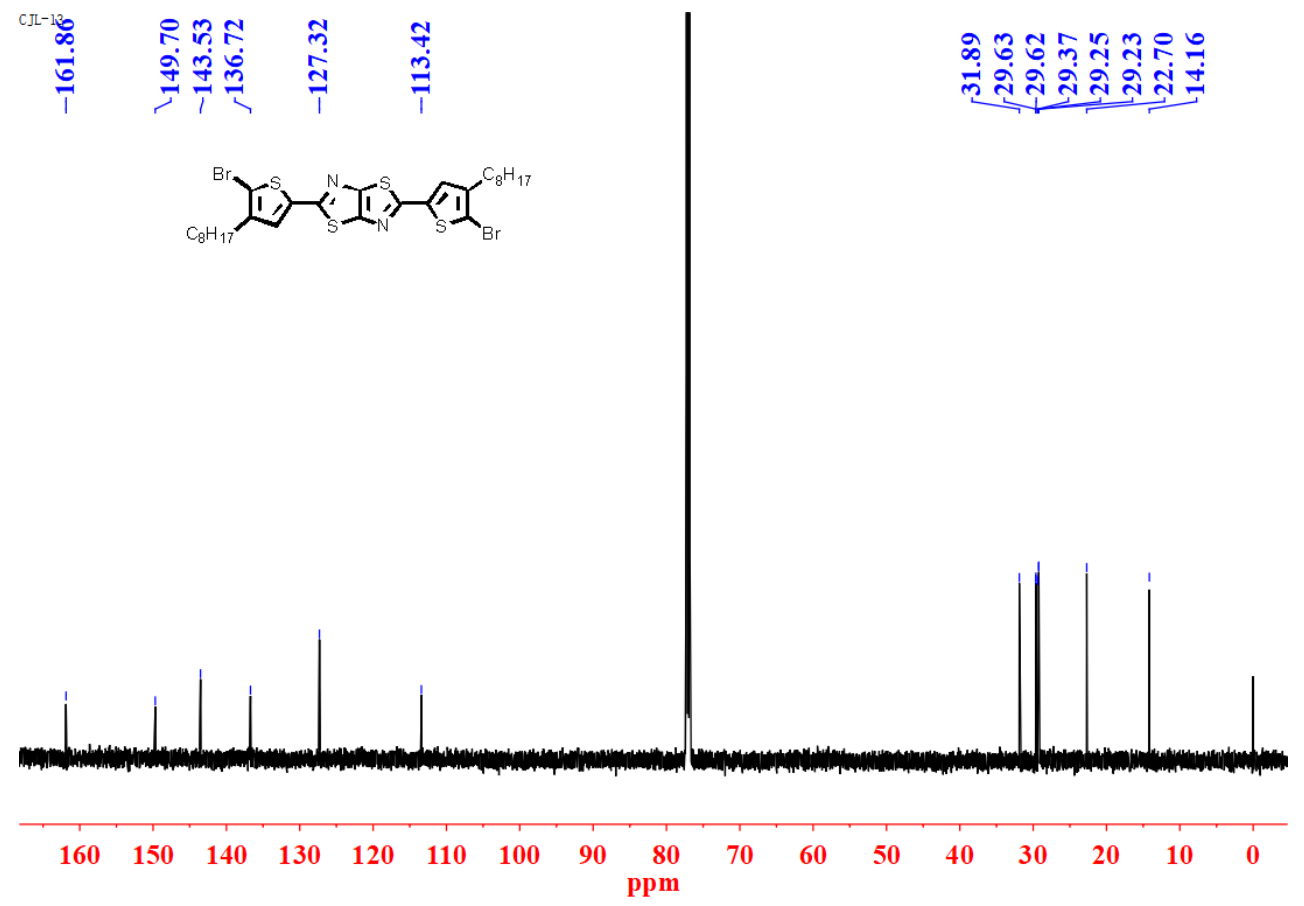

Figure S22. ${ }^{13} \mathrm{C}$ NMR spectrum of Compound $\mathbf{M 3}{ }^{1}$. Reprinted with permission from the publisher. Copyright (C 2019, American Chemical Society 


\section{References}

(1) Cao, Z.; Chen, J.; Liu, S.; Qin, M.; Jia, T.; Zhao, J.; Li, Q.; Ying, L.; Cai, Y.-P.; Lu, X.; Huang, F.; Cao, Y. Understanding of Imine Substitution in Wide-Bandgap Polymer Donor-Induced Efficiency Enhancement in All-Polymer Solar Cells. Chem. Mater. 2019, 31, 8533-8542.

(2) Kirby, N. M.; Mudie, S. T.; Hawley, A. M.; Cookson, D. J.; Mertens, H. D. T.; Cowieson, N.; Samardzic-Boban, V. A Low-Background-Intensity Focusing Small-Angle X-Ray Scattering Undulator Beamline. J. Appl. Crystallogr. 2013, 46, $1670-1680$.

(3) Blom, P. W. M.; de Jong, M. J. M.; van Munster, M. G. Electric-Field and Temperature Dependence of the Hole Mobility in Poly(P-Phenylene Vinylene). Phys. Rev. B 1997, 55, R656-R659.

(4) Li, Z.; Jiang, K.; Yang, G.; Lai, J. Y. L.; Ma, T.; Zhao, J.; Ma, W.; Yan, H. Donor

Polymer Design Enables Efficient Non-Fullerene Organic Solar Cells. Nat. Commun. 2016, 7, 13094.

(5) Jiang, K.; Wei, Q.; Lai, J. Y. L.; Peng, Z.; Kim, H. K.; Yuan, J.; Ye, L.; Ade, H.; Zou, Y.; Yan, H. Alkyl Chain Tuning of Small Molecule Acceptors for Efficient Organic Solar Cells. Joule 2019, 3, 3020-3033. 